\title{
Impact of reactive bromine chemistry in the troposphere
}

\author{
R. von Glasow ${ }^{1,2}$, R. von Kuhlmann ${ }^{3,4}$, M. G. Lawrence ${ }^{3}$, U. Platt ${ }^{2}$, and P. J. Crutzen ${ }^{2,3}$ \\ ${ }^{1}$ Institute for Environmental Physics, Universität Heidelberg, Germany \\ ${ }^{2}$ Center for Atmospheric Sciences, Scripps Institution of Oceanography, University of California, San Diego, USA \\ ${ }^{3}$ Atmospheric Chemistry Division, Max-Planck-Institut für Chemie, Mainz, Germany \\ ${ }^{4}$ now at: German Aerospace Center (DLR), Bonn-Oberkassel, Germany
}

Received: 28 June 2004 - Published in Atmos. Chem. Phys. Discuss.: 24 August 2004

Revised: 2 December 2004 - Accepted: 7 December 2004 - Published: 8 December 2004

\begin{abstract}
Recently several field campaigns and satellite observations have found strong indications for the presence of bromine oxide $(\mathrm{BrO})$ in the free troposphere. Using a global atmospheric chemistry transport model we show that $\mathrm{BrO}$ mixing ratios of a few tenths to $2 \mathrm{pmol} \mathrm{mol}^{-1}$ lead to a reduction in the zonal mean $\mathrm{O}_{3}$ mixing ratio of up to $18 \%$ in widespread areas and regionally up to $40 \%$ compared to a model run without bromine chemistry. A lower limit approach for the marine boundary layer, that does not explicitly include the release of halogens from sea salt aerosol, shows that for dimethyl sulfide (DMS) the effect is even larger, with up to $60 \%$ reduction of its tropospheric column. This is accompanied by dramatic changes in DMS oxidation pathways, reducing its cooling effect on climate. In addition there are changes in the $\mathrm{HO}_{2}: \mathrm{OH}$ ratio that also affect $\mathrm{NO}_{\mathrm{x}}$ and PAN. These results imply that potentially significant strong sinks for $\mathrm{O}_{3}$ and DMS have so far been ignored in many studies of the chemistry of the troposphere.
\end{abstract}

\section{Introduction}

In the last two decades reactive halogens have been identified as important reactants in the troposphere (see e.g. von Glasow and Crutzen (2003) for an overview). BrO has been found in the boundary layer during polar ozone depletion events (ODEs) (Hausmann and Platt, 1994), over salt lakes (Hebestreit et al., 1999; Stutz et al., 2002; Hönninger et al., 2004), and in the marine boundary layer (MBL) (Leser et al., 2003; Saiz-Lopez et al., 2004) and also in volcanic plumes (Bobrowski et al. (2003), N. Bobrowski, pers. comm.). Satellite observations showed the widespread presence of $\mathrm{BrO}$ in the troposphere outside the polar regions (Wagner and Platt, 1998; Pundt et al., 2000; Fitzenberger et al., 2000;

Correspondence to: R. von Glasow

(Roland.von.Glasow@iup.uni-heidelberg.de)
Wagner et al., 2001; Van Roozendael et al., 2002; Richter et al., 2002; Hollwedel et al., 2003) with global background vertical columns of about $1-3 \times 10^{13}$ molec $\mathrm{cm}^{-2}$, corresponding to $\mathrm{BrO}$ mixing ratios of $0.5-2 \mathrm{pmol} \mathrm{mol}^{-1}$ if uniformly mixed in the troposphere. Comparisons with balloon and ground based measurements in mid and high northern latitudes (between 42 and $68^{\circ} \mathrm{N}$, Harder et al. (1998); Fitzenberger et al. (2000); Van Roozendael et al. (2002)) as well as the diurnal variation of ground based $\mathrm{BrO}$ column measurements (Van Roozendael et al., 2002) indicated that the tropospheric $\mathrm{BrO}$ was mainly located within the free troposphere (FT). Direct evidence for free tropospheric $\mathrm{BrO}$ in the Arctic comes from balloon (Fitzenberger et al., 2000) and highaltitude aircraft observations (McElroy et al., 1999). Such observations have not been made yet at lower latitudes. Although most evidence indicates that the measured $\mathrm{BrO}$ is located in the FT, these data do not exclude contributions from the MBL. Ongoing work is estimating tropospheric vertical columns of $\mathrm{BrO}$ from satellite data but it is expected to yield reliable data only in the polar regions or other regions of strongly elevated $\mathrm{BrO}$ (J. Hollwedel, pers. comm.).

Halogens affect ozone by directly destroying it and by reducing its production. The main destruction cycle is (the numbers in parentheses refer to the numbering of the reactions in Table 2):

$$
\begin{aligned}
\mathrm{O}_{3}+\mathrm{Br} & \longrightarrow \mathrm{BrO}+\mathrm{O}_{2} \\
\mathrm{BrO}+\mathrm{HO}_{2} & \longrightarrow \mathrm{HOBr}+\mathrm{O}_{2} \\
\mathrm{HOBr}+\mathrm{h} v & \longrightarrow \mathrm{OH}+\mathrm{Br}
\end{aligned}
$$

$$
\text { I net: } \mathrm{O}_{3}+\mathrm{HO}_{2}+\mathrm{h} v \longrightarrow 2 \mathrm{O}_{2}+\mathrm{OH}
$$

Uptake of $\mathrm{HOBr}$ is an alternative route for reaction (Br16) which cycles Br back to the gas phase. The simplest catalytic ozone production cycle is:

$$
\begin{aligned}
\mathrm{CO}+\mathrm{OH} \stackrel{\mathrm{O}_{2}}{\longrightarrow} \mathrm{CO}_{2}+\mathrm{HO}_{2} \\
\mathrm{HO}_{2}+\mathrm{NO} \longrightarrow \mathrm{OH}+\mathrm{NO}_{2}
\end{aligned}
$$




\begin{aligned} & $\mathrm{NO}_{2}+\mathrm{h} v \longrightarrow \mathrm{NO}+\mathrm{O} \\ & \mathrm{O}+\mathrm{O}_{2} \longrightarrow \mathrm{O}_{3} \\ &$\hline\end{aligned}

II net: $\mathrm{CO}+2 \mathrm{O}_{2}+\mathrm{h} v \longrightarrow \mathrm{CO}_{2}+\mathrm{O}_{3}$

This is being "shortcut" by cycle I which converts $\mathrm{HO}_{2}$ back to $\mathrm{OH}$ without oxidizing $\mathrm{NO}$ to $\mathrm{NO}_{2}$. The net effect on odd oxygen $\left(=\mathrm{O}_{\mathrm{x}}\right)$ is therefore to destroy one molecule of $\mathrm{O}_{\mathrm{x}}(=\mathrm{BrO})$ instead of producing one $\left(=\mathrm{NO}_{2}\right)$ where $\mathrm{O}_{\mathrm{x}}$ is defined based on Crutzen and Schmailzl (1983) as $\mathrm{O}_{\mathrm{x}}=\mathrm{O}_{3}+\mathrm{O}+\mathrm{O}\left({ }^{1} \mathrm{D}\right)+\mathrm{NO}_{2}+2 \mathrm{NO}_{3}+3 \mathrm{~N}_{2} \mathrm{O}_{5}+\mathrm{HNO}_{4}+\mathrm{ClO}$ $+2 \mathrm{Cl}_{2} \mathrm{O}_{2}+2 \mathrm{OClO}+\mathrm{BrO}$. Another "shortcut" occurs in the $\mathrm{NO}_{\mathrm{x}}$ cycle:

$$
\mathrm{BrO}+\mathrm{NO} \longrightarrow \mathrm{Br}+\mathrm{NO}_{2}
$$

As both $\mathrm{BrO}$ and $\mathrm{NO}_{2}$ are members of the $\mathrm{O}_{\mathrm{x}}$ family, this cycle oxidizes $\mathrm{NO}$ to $\mathrm{NO}_{2}$ without changing the sum of $\mathrm{O}_{\mathrm{x}}$ (see also discussion in e.g. Stutz et al. (1999); Platt and Hönninger (2003)). Reaction ( $\mathrm{Br} 9)$, however, does not lead to a change of the $\mathrm{NO}$ to $\mathrm{NO}_{2}$ ratio on a global scale as explained in Sect. 3.4.

In this study we examine the potential effects of the presence of $0.5-2 \mathrm{pmol} \mathrm{mol}^{-1}$ of $\mathrm{BrO}$ on the photochemistry (mainly ozone and DMS) in the (free) troposphere and discuss where we should focus our future research in this field. We describe the model and the source scenarios that we used in Sect. 2 and will discuss the implications for tropospheric chemistry in Sect. 3 focussing on $\mathrm{O}_{3}, \mathrm{HO}_{\mathrm{x}}, \mathrm{NO}_{\mathrm{x}}$, and DMS. In Sect. 4 we conclude and list future research needs.

\section{Model description and source scenarios}

For this study we used the three-dimensional chemical transport model MATCH-MPIC (Lawrence et al., 1999; von Kuhlmann et al., 2003) which includes a comprehensive treatment of tropospheric gas phase chemistry including nonmethane hydrocarbons. We added reactions relevant for bromine processing and bromine-related ozone destruction and the oceanic sources of DMS after Kettle et al. (1999) and its destruction by $\mathrm{OH}, \mathrm{NO}_{3}, \mathrm{BrO}$, and $\mathrm{Br}$. The additional reactions are listed in Table 2. Wet and dry deposition are included as a function of the Henry's law constant of the respective compounds.

The actual sources for the tropospheric inorganic bromine $\left(\mathrm{Br}_{\text {inorg }}\right)$ are still poorly constrained. They include downward transport from the stratosphere in mid to high latitudes, "spillout" and uplifting from polar surface ODEs, upward transport from the marine boundary layer, volcanoes, organohalogens (e.g. $\mathrm{CH}_{3} \mathrm{Br}, \mathrm{CH}_{2} \mathrm{Br}_{2}, \mathrm{CHBr}_{3}$, and $\mathrm{CHBr}_{2} \mathrm{Cl}$ ) which are broken down by photolysis and/or reaction with $\mathrm{OH}$, release of inorganic halogens by biomass burning as shown in laboratory experiments (B. Keene, pers. comm.), or other, so far unidentified processes. Many of these sources will have a seasonal cycle which we do not take into account in this exploratory study. To sustain a tropospheric mixing ratio of $\mathrm{Br}_{\text {inorg }}$ of about $3 \mathrm{pmol} \mathrm{mol}^{-1}$ and assuming a $\mathrm{Br}_{\text {inorg }}$ lifetime of 1-2 weeks in the FT a global source of $2.5-5 \times 10^{-18} \mathrm{~mol} \mathrm{~mol}^{-1} \mathrm{~s}^{-1}$ or about 5.6$11 \times 10^{7}$ molec $\mathrm{cm}^{-2} \mathrm{~s}^{-1}$ would be needed. It is likely that the total source is actually composed of several of the aforementioned sources.

To reproduce the previously mentioned mixing ratios of $\mathrm{BrO}$ in the FT we tested four different hypothetical source scenarios (see Table 1): "tropics", "high lat", "const", and "strat" which reflect different possible source types/regions, namely the tropics, high latitudes, a source constant with latitude, and only downward flux of inorganic bromine from the stratosphere plus photochemical breakdown of $\mathrm{CH}_{3} \mathrm{Br}$. We have chosen this set of model runs to study the differences in the impacts related to these spatial distributions of BrO. Except for the case "strat" we do not differentiate in any of these scenarios between the possible sources that we have mentioned above. As no good global data on the different source processes is available we cannot derive source scenarios that explicitly take the spatial coverage of single sources into account. Furthermore, the scarcity of observational data does not allow us to chose one of these scenarios as a "best guess".

For the scenario "tropics" we used the simplified reaction:

$$
\mathrm{Br}_{\mathrm{org}}+\mathrm{OH} \longrightarrow \mathrm{Br}+\text { products }
$$

with a generic organic bromine compound $\mathrm{Br}_{\text {org }}$ (with fixed mixing ratio of $30 \mathrm{pmol} \mathrm{mol}^{-1} \mathrm{Br}$ ) as bromine source, constituting a bromine source of about $100 \mathrm{molec} \mathrm{cm}^{-3} \mathrm{~s}^{-1}$ at a temperature of $\mathrm{T}=250 \mathrm{~K}$ and an $\mathrm{OH}$ concentration of $10^{6}$ molec $\mathrm{cm}^{-3}$. The $\mathrm{OH}$ dependence ensures a direct coupling with the photochemistry and makes this bromine source most important in the tropics where $\mathrm{OH}$ concentrations are highest.

The bromine source of the scenario "high lat" is independent of photochemistry and increasing with latitude, corresponding to a dominance of downward transport from the stratosphere and spillout from polar surface ODEs. We used $F_{\text {high lat }}=(15+0.5 \phi) \frac{[M(\phi)]}{\left[M_{0}(\phi)\right]}$ molec $\mathrm{cm}^{-3} \mathrm{~s}^{-1}$, where $\phi$ is the latitude in degrees and $[M]$ and $\left[M_{0}\right]$ the concentration of air molecules at current altitude and at the surface, respectively.

In the scenario "const" the source is also independent of photochemistry but constant with latitude, $F_{\text {const }}=34 \frac{[M(\phi)]}{\left[M_{0}(\phi)\right]}$ molec $\mathrm{cm}^{-3} \mathrm{~s}^{-1}$. In scenarios "high lat" and "const" no time dependence of the bromine source was assumed, whereas the dependence on $[\mathrm{OH}]$ in scenario "tropics" leads to a diurnally and seasonally varying bromine source.

The scaling with the concentration of air molecules in scenarios "high lat" and"const" ensures that the $\mathrm{Br}_{\text {inorg }}$ source is constant with altitude in mixing ratio $\left(\mathrm{mol} \mathrm{mol}^{-1} \mathrm{~s}^{-1}\right)$ but obviously not in concentration ( $\operatorname{molec~} \mathrm{cm}^{-3} \mathrm{~s}^{-1}$ ). Due to different chemical regimes and washout rates the impact and 
Table 1. Overview of scenarios used in this study.

\begin{tabular}{|c|c|c|}
\hline scenario & heterogeneous bromine reactions & description \\
\hline high lat & $\mathrm{k}_{h e t}=10 . \times \mathrm{k}_{h e t}(\gamma=0.1)^{a}$ & $\mathrm{Br}$ source increases with latitude \\
\hline high lat, slow recyc. & $\gamma=0.1$ & $\mathrm{Br}$ source increases with latitude \\
\hline high lat, no recyc. & off & $\mathrm{Br}$ source increases with latitude \\
\hline const & $\mathrm{k}_{h e t}^{\prime}=10 . \times \mathrm{k}_{h e t}(\gamma=0.1)^{a}$ & $\mathrm{Br}$ source constant with latitude \\
\hline tropics & $\mathrm{k}_{h e t}^{\prime}=10 . \times \mathrm{k}_{h e t}(\gamma=0.1)^{a}$ & Br source decreases with latitude \\
\hline $\begin{array}{l}\text { strat } \\
\text { nohal }\end{array}$ & $\begin{array}{l}\mathrm{k}_{h e t}^{\prime}=10 . \times \mathrm{k}_{h e t}(\gamma=0.1)^{a} \\
\text { off }\end{array}$ & $\begin{array}{l}\text { Br downward transport from stratosphere plus decomposition of } \mathrm{CH}_{3} \mathrm{Br} \\
\text { no bromine }\end{array}$ \\
\hline
\end{tabular}

${ }^{a}$ see explanation in text, the effective gamma for these runs is approx. $\gamma=0.5$.

Table 2. Bromine reactions.

\begin{tabular}{|c|c|c|c|c|c|}
\hline no & reaction & $n$ & $A\left[\left(\mathrm{~cm}^{-3}\right)^{1-n} \mathrm{~s}^{-1}\right]$ & $-E_{a} / R[\mathrm{~K}]$ & Reference \\
\hline $\mathrm{Br} 1$ & $\mathrm{Br}+\mathrm{O}_{3} \rightarrow \mathrm{BrO}+\mathrm{O}_{2}$ & 2 & $1.7 \times 10^{-11}$ & -800 & Sander et al. (2003) \\
\hline $\operatorname{Br} 2$ & $\mathrm{Br}+\mathrm{HO}_{2} \longrightarrow \mathrm{HBr}+\mathrm{O}_{2}$ & 2 & $1.5 \times 10^{-11}$ & -600 & Sander et al. (2003) \\
\hline $\operatorname{Br} 3$ & $\mathrm{Br}+\mathrm{C}_{2} \mathrm{H}_{4} \stackrel{\mathrm{O}_{2}}{\longrightarrow} \mathrm{HBr}+\mathrm{C}_{2} \mathrm{H}_{5} \mathrm{O}_{2}$ & 2 & $5 . \times 10^{-14}$ & & Singh and Zimmerman (1992) \\
\hline $\operatorname{Br} 4$ & $\mathrm{Br}+\mathrm{HCHO} \stackrel{\mathrm{O}_{2}}{\longrightarrow} \mathrm{HBr}+\mathrm{CO}+\mathrm{HO}_{2}$ & 2 & $1.7 \times 10^{-11}$ & -800 & Sander et al. (2003) \\
\hline $\operatorname{Br} 5$ & $\mathrm{Br}+\mathrm{CH}_{3} \mathrm{OOH} \longrightarrow \mathrm{CH}_{3} \mathrm{OO}+\mathrm{HBr}$ & 2 & $2.66 \times 10^{-12}$ & -1610 & Mallard et al. (1993) \\
\hline $\operatorname{Br} 6$ & $\mathrm{Br}+\mathrm{BrNO}_{3} \longrightarrow \mathrm{Br}_{2}+\mathrm{NO}_{3}$ & 2 & $4.9 \times 10^{-11}$ & & Orlando and Tyndall (1996) \\
\hline $\mathrm{Br} 7$ & $\mathrm{BrO}+\mathrm{HO}_{2} \longrightarrow \mathrm{HOBr}+\mathrm{O}_{2}$ & 2 & $3.4 \times 10^{-12}$ & 540 & Sander et al. (2003) \\
\hline $\operatorname{Br} 8$ & $\mathrm{BrO}+\mathrm{CH}_{3} \mathrm{OO} \longrightarrow 0.72 \mathrm{HOBr}+0.28 \mathrm{Br}+0.28 \mathrm{HO}_{2}+\mathrm{HCHO}^{a}$ & 2 & $5.7 \times 10^{-12}$ & & Aranda et al. (1997) \\
\hline $\operatorname{Br} 9$ & $\mathrm{BrO}+\mathrm{NO} \longrightarrow \mathrm{Br}+\mathrm{NO}_{2}$ & 2 & $8.8 \times 10^{-12}$ & 260 & Sander et al. (2003) \\
\hline $\operatorname{Br} 10$ & $\mathrm{BrO}+\mathrm{NO}_{2} \stackrel{M}{\longrightarrow} \mathrm{BrNO}_{3}$ & 2 & $b$ & & Sander et al. (2003) \\
\hline $\operatorname{Br} 11$ & $\mathrm{BrO}+\mathrm{BrO} \longrightarrow 1.62 \mathrm{Br}+0.19 \mathrm{Br}_{2}+\mathrm{O}_{2}$ & 2 & $2.95 \times 10^{-12}$ & 40 & $\begin{array}{l}\text { based on Sander et al. (2003), } 2 \text { channels } \\
\text { (different T-dependence) combined }\end{array}$ \\
\hline $\operatorname{Br} 12$ & $\mathrm{HBr}+\mathrm{OH} \longrightarrow \mathrm{Br}+\mathrm{H}_{2} \mathrm{O}$ & 2 & $1.1 \times 10^{-11}$ & & Sander et al. (2003) \\
\hline $\operatorname{Br} 13$ & $\mathrm{BrNO}_{3} \longrightarrow \mathrm{BrO}+\mathrm{NO}_{2}$ & 1 & $b$ & & Orlando and Tyndall (1996) \\
\hline $\operatorname{Br} 14$ & $\mathrm{BrO}+h v \stackrel{\mathrm{O}_{2}}{\longrightarrow} \mathrm{Br}+\mathrm{O}_{3}$ & 1 & $c$ & & DeMore et al. (1997) \\
\hline $\operatorname{Br} 15$ & $\mathrm{Br}_{2}+h v \longrightarrow 2 \mathrm{Br}$ & 1 & $c$ & & Hubinger and Nee (1995) \\
\hline $\operatorname{Br} 16$ & $\mathrm{HOBr}+h v \longrightarrow \mathrm{Br}+\mathrm{OH}$ & 1 & $c$ & & Ingham et al. (1999) \\
\hline $\operatorname{Br} 17$ & $\mathrm{BrNO}_{3}+h \nu \longrightarrow \mathrm{Br}+\mathrm{NO}_{3}$ & 1 & $c$ & & DeMore et al. (1997) \\
\hline $\operatorname{Br} 18$ & $\mathrm{HOBr}+\mathrm{HBr} \stackrel{\text { het }}{\longrightarrow} \mathrm{Br}_{2}(+.)$. & 2 & & & see text \\
\hline $\operatorname{Br} 19$ & $\mathrm{BrNO}_{3} \stackrel{\text { het }}{\longrightarrow} \mathrm{HOBr}(+.)$. & 1 & & & see text \\
\hline $\operatorname{Br} 20$ & $\mathrm{Br}_{\text {org }}+\mathrm{OH} \longrightarrow \mathrm{Br}(+.)$. & 2 & $1.7 \times 10^{-11}$ & -1215 & assumed, only for "tropics", $\left[\mathrm{Br}_{\text {org }}\right]=30 \mathrm{pmol} \mathrm{mol}^{-1}$ \\
\hline $\operatorname{Br} 21$ & $\mathrm{CH}_{3} \mathrm{Br}+\mathrm{OH} \longrightarrow \mathrm{Br}(+.)$. & 2 & $1.7 \times 10^{-12}$ & -1215 & Atkinson et al. (2003), only for "strat" \\
\hline S1 & $\mathrm{DMS}+\mathrm{OH} \stackrel{\mathrm{O}_{3}}{\longrightarrow}\left(\mathrm{CH}_{3} \mathrm{SO} 2+\right) \mathrm{HCHO}^{d}$ & 2 & $1.12 \times 10^{-11}$ & -253 & after Atkinson et al. (1997) \\
\hline S2 & $\mathrm{DMS}+\mathrm{OH} \longrightarrow\left(0.5 \mathrm{DMSO}+0.5 \mathrm{SO}_{2}+\right) 0.5 \mathrm{HO}_{2}+\mathrm{CH}_{3} \mathrm{OO}^{d}$ & 2 & $b$ & & after Atkinson et al. (1997) \\
\hline S3 & $\mathrm{DMS}+\mathrm{NO}_{3} \stackrel{\mathrm{O}_{3}}{\longrightarrow}\left(\mathrm{CH}_{3} \mathrm{SO}_{2}+\right) \mathrm{HNO}_{3}+\mathrm{HCHO}^{d}$ & 2 & $1.9 \times 10^{-13}$ & 520 & Atkinson et al. (1999) \\
\hline S4 & $\mathrm{DMS}+\mathrm{Br} \stackrel{\mathrm{O}_{3}}{\longrightarrow}\left(\mathrm{CH}_{3} \mathrm{SO}_{2}+\right) \mathrm{HBr}+\mathrm{HCHO}^{d}$ & 2 & $9.0 \times 10^{-11}$ & -2386 & Jefferson et al. (1994) \\
\hline S5 & $\mathrm{DMS}+\mathrm{BrO} \longrightarrow(\mathrm{DMSO}+) \mathrm{Br}$ & 2 & $2.54 \times 10^{-14}$ & 850 & Ingham et al. (1999) \\
\hline
\end{tabular}

$n$ is the order of the reaction. ${ }^{a}$ two reactions combined, ${ }^{b}$ special rate functions (pressure dependent), ${ }^{c}$ photolysis rates calculated online, $d$ simplified final products of importance for $\mathrm{HO}_{\mathrm{x}}$ chemistry included. The rate coefficients are calculated with $k=A \times \exp \left(\frac{-E_{a}}{R T}\right)$. Note that the breakdown products of DMS are ignored in the model. 
lifetime and therefore "steady state" mixing ratio is dependent on altitude and latitude.

The only bromine sources in scenario "strat" are downward flux of inorganic bromine from the stratosphere and decomposition of $\mathrm{CH}_{3} \mathrm{Br}$ (with a constant mixing ratio of $10 \mathrm{pmol} \mathrm{mol}^{-1}$ ) in the troposphere by reaction with $\mathrm{OH}$. To calculate the downward flux we used fixed concentrations of inorganic bromine in the stratosphere (dependent on latitude and season) as a boundary condition, the data are taken from a two-dimensional stratospheric model (Brühl et al., 1998; WMO, 2003). As explained by von Kuhlmann et al. (2003) a factor of 0.5 has to be used to improve the stratospheretroposphere exchange of $\mathrm{O}_{3}$ in the model. In the scenario "strat" we applied the same ratio for the downward flux of inorganic bromine.

If only gas phase reactions are included, the cycling of $\mathrm{HOBr}, \mathrm{HBr}$, and $\mathrm{BrNO}_{3}$ is rather slow and the resulting $\mathrm{BrO}$ concentrations are small. It was shown in many studies, however, that very efficient cycling of inorganic bromine occurs on and within aerosol particles (see e.g. overview by von Glasow and Crutzen (2003) and references therein). Our simplified approach for the heterogeneous reactions is:

$$
\begin{aligned}
\mathrm{HOBr}+\mathrm{HBr} & \stackrel{\text { het }}{\longrightarrow} \mathrm{Br}_{2}(+. .) \\
\mathrm{BrNO}_{3} & \stackrel{\text { het }}{\longrightarrow} \mathrm{HOBr}(+. .)
\end{aligned}
$$

based on detailed reaction cycles (Fan and Jacob, 1992; Abbatt, 1994; Vogt et al., 1996; Sander et al., 1999; Fickert et al., 1999). In the current model version no aqueous phase species are considered, therefore we listed only the gas phase products, other products are assumed to be taken up irreversibly by the aerosol. We used the approach of the reaction of $\mathrm{HOBr}$ with $\mathrm{HBr}$ on aerosol surfaces because of the high solubility of $\mathrm{HBr}$, a possible enrichment of bromide on the aerosol surface (Jungwirth and Tobias, 2002), and the already mentioned high reaction probabilities on aerosols. Note that reaction (Br19) constitutes loss of $\mathrm{NO}_{\mathrm{x}}$ for the gas phase (see discussion in Sect. 3.4). We used the heterogeneous reaction rates as calculated by Dentener and Crutzen (1993) (based on Langner and Rodhe (1991)) that were derived based on climatological monthly mean values for all meteorological parameters (e.g. relative humidity), a reaction probability of $\gamma=0.1$, and taking gas phase diffusion limitations into account. To investigate the implications of bromine recycling on aerosol we repeated scenario "high lat" without aerosol recycling ("no recycling") and a 10 times faster recycling rate $\left(\mathrm{k}^{\prime}\right.$ het $\left.=10 . \times \mathrm{k}_{\text {het }}(\gamma=0.1)\right)$ which approximately corresponds to $\gamma=0.5$ for the size distribution chosen by Dentener and Crutzen (1993). Very high reaction probabilities of the involved bromine species have been observed on different substrates (Sander et al., 2003), and, as explained below, the results with faster heterogenous reaction rates yield better agreement with the available information on BrO tropospheric vertical columns, therefore we used the higher re- cycling rate $\mathrm{k}^{\text {' }}$ et for all scenarios except for "high lat, no recycling" and "high lat, slow recycling".

Many details of the bromine recycling are still unknown, cycling of $\mathrm{HOBr}$ on frozen salt surfaces (Adams et al., 2002) or cirrus clouds, or in stratiform clouds (von Glasow et al., $2002 \mathrm{~b}$ ) are additional routes. If these bromine recycling reactions or other processes that reduce the loss of inorganic bromine are confirmed to be of importance, a smaller source for inorganic bromine would be needed to reproduce the reported $\mathrm{BrO}$ mixing ratios.

As already mentioned, the actual recycling of inorganic halogens on aerosols happens in a more complicated way but by using this approach we assume a dependence on the available aerosol surface area and yield $\mathrm{BrO}$ mixing ratios that are close to those deduced from satellite observations and balloon measurements (see Sect. 3.1). No aerosol components are transported in the current model version, so potential accumulation effects on the aerosol or a spatial redistribution of bromine by transport/settling of aerosol and time-delayed release of inorganic bromine from the aerosol cannot be simulated in this model version.

A model resolution of $11.25^{\circ} \times 11.25^{\circ}$ at the equator (T10) with 28 vertical levels is used. This is sufficiently high to examine the large scale features and the overall effects of bromine especially considering the uncertainties in the source strength and distribution. All scenarios were run for 12 months after a spinup of 16 months each.

\section{Results}

\section{1 $\mathrm{Br}_{\text {inorg }}$ distributions}

We start by briefly discussing the distribution of bromine species in the different scenarios before we explain the impacts of bromine on other trace gases focusing on the free troposphere. As explained in the previous section we use artificial in situ sources for bromine in order to analyze the atmospheric response based on different latitudinal distributions of bromine. These sources do not explicitly take sea salt aerosol into account, therefore the bromine levels in the boundary layer in all runs - and all related consequences for photochemistry - are lower limits. This setup was chosen because the main purpose of this study is to investigate effects in the free troposphere and to provide lower limit estimates for the boundary layer. Ongoing work deals with the explicit treatment of sea salt aerosol chemistry on a global scale.

Total tropospheric $\mathrm{Br}_{\text {inorg levels in all scenarios are about }}$ $1-6 \mathrm{pmol} \mathrm{mol}^{-1}$ (see e.g. Fig. 1 for scenario "high lat") except for run "strat" where they are below $1 \mathrm{pmol} \mathrm{mol}^{-1}$. In scenarios with a faster recycling rate compared to runs with slower or no recycling $\mathrm{Br}_{\text {inorg }}$ increases by more than $200 \%$ in regions with high wet deposition rates, i.e. the tropics but also in southern mid latitudes in altitudes of 900 to $500 \mathrm{hPa}$. Faster recycling implies higher $\mathrm{BrO}: \mathrm{Br}_{\text {inorg }}$ and 


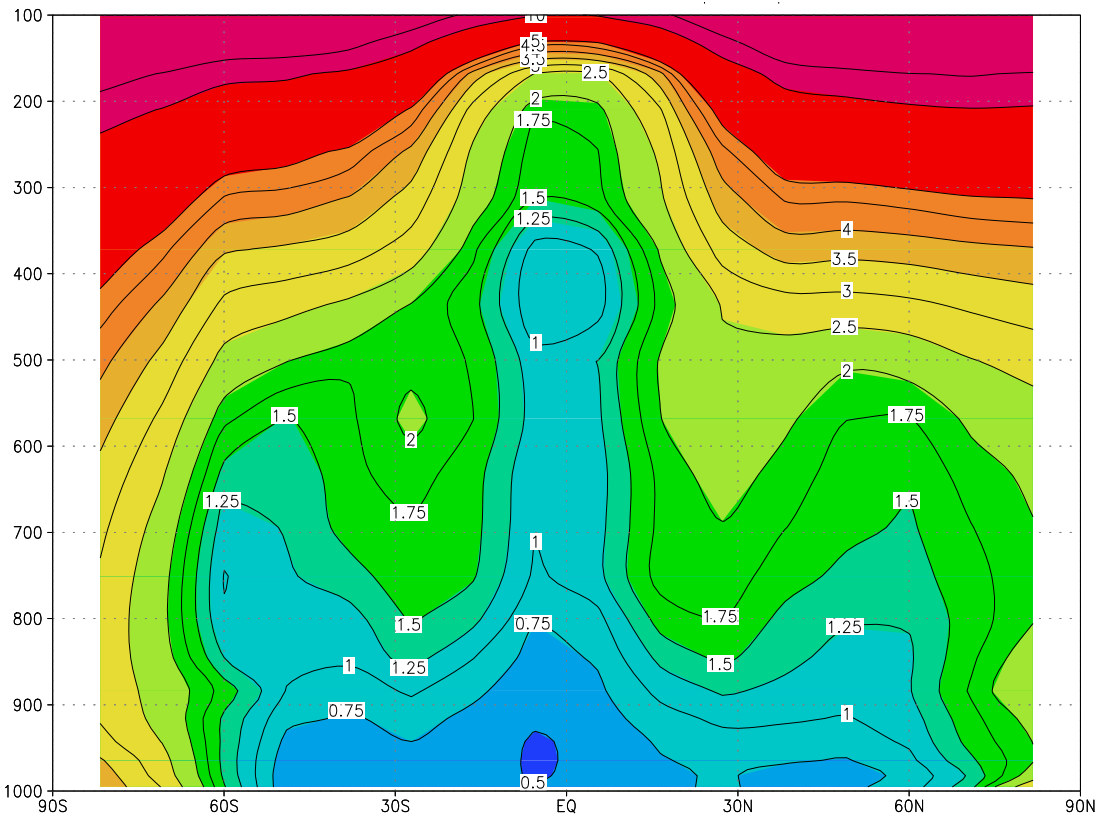

Fig. 1. Zonally and annually averaged mean of the $\mathrm{Br}_{\text {inorg }}$ mixing ratio (in pmol mol ${ }^{-1}$ ) resulting from our source scenario "high lat". The ordinate is the $\sigma$-level multiplied by 1000 which is approximately the pressure in $\mathrm{hPa}$ and the abscissa is latitude in degrees. Note that $24 \mathrm{~h}$ averages are plotted. Seasalt aerosol is not explicitly included as a source therefore boundary layer values are lower limits.

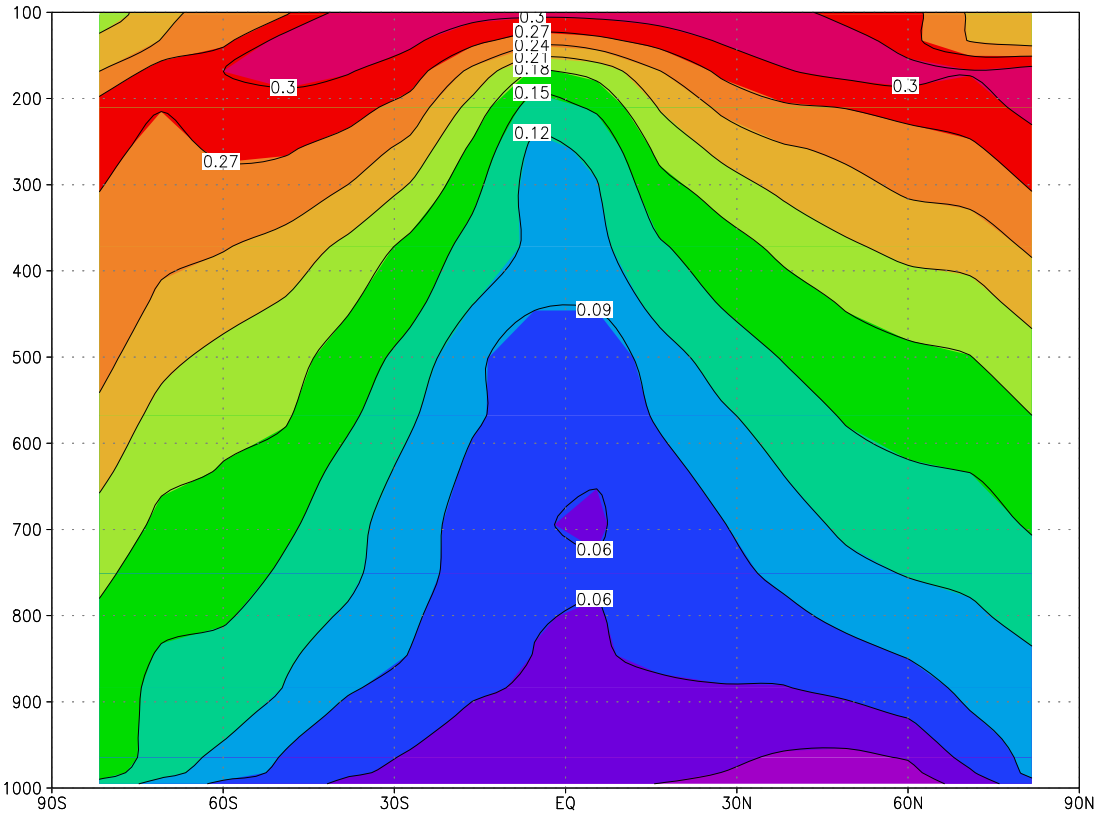

Fig. 2. Zonally and annually averaged mean of the ratio of $\mathrm{BrO}$ to $\mathrm{Br}_{\text {inorg }}$ resulting from our source scenario "high lat". The ordinate is the $\sigma$-level multiplied by 1000 which is approximately the pressure in $\mathrm{hPa}$ and the abscissa is latitude in degrees. Note that $24 \mathrm{~h}$ averages are plotted.

$\mathrm{Br}_{2}: \mathrm{Br}_{\text {inorg }}$ values and therefore less deposition as these two species are relatively insoluble. $\mathrm{HBr}$ and $\mathrm{BrNO}_{3}$ (and $\mathrm{HOBr}$ ), on the other hand, get washed out rapidly. In the "tropics" scenario $\mathrm{Br}_{\text {inorg }}$ mixing ratios in the tropics are up to $5 \mathrm{pmol} \mathrm{mol}^{-1}$ and only around $2 \mathrm{pmol} \mathrm{mol}^{-1}$ in high latitudes whereas in the case "high lat" they are less than $2 \mathrm{pmol} \mathrm{mol}^{-1}$ in the tropics and up to $5 \mathrm{pmol} \mathrm{mol}^{-1}$ in high latitudes. In the scenario "const" the numbers are similar 


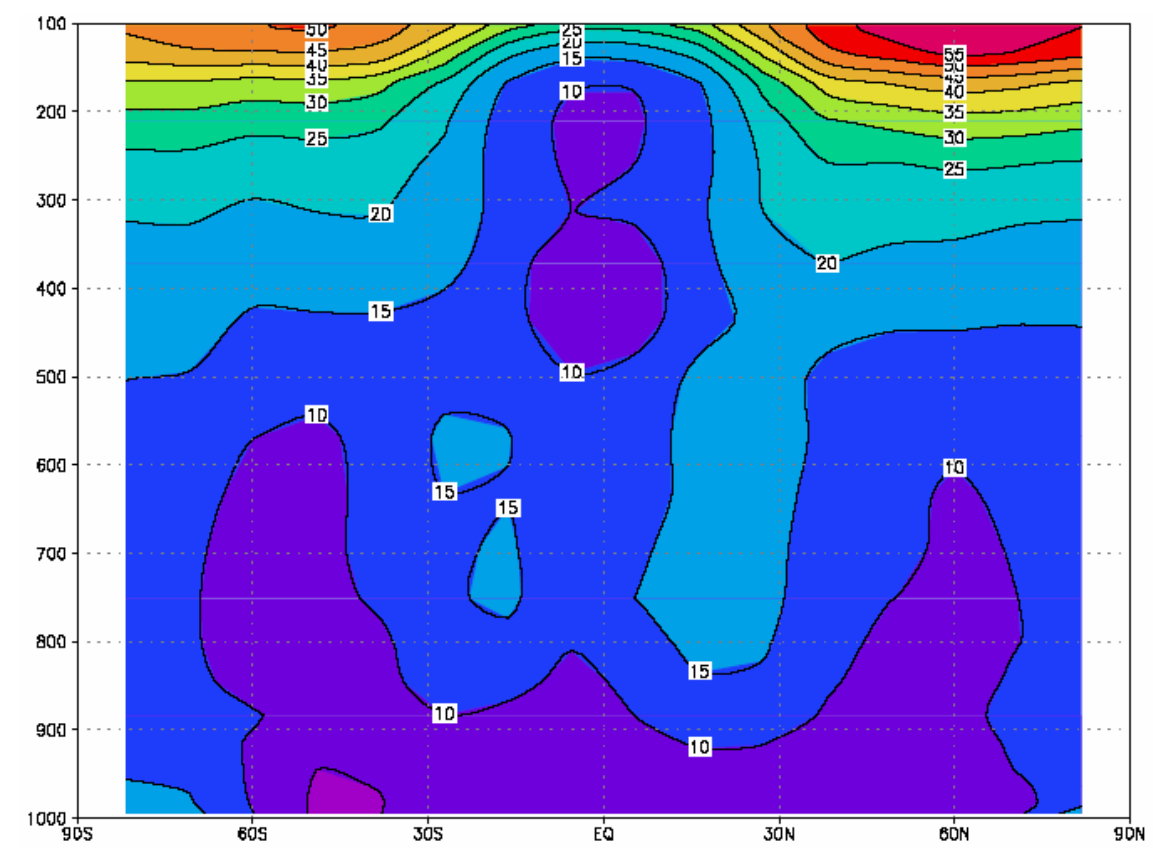

Fig. 3. Zonally and annually averaged mean of the lifetime of $\mathrm{Br}_{\text {inorg }}$ (in days) resulting from our source scenario "high lat". The ordinate is the $\sigma$-level multiplied by 1000 which is approximately the pressure in $\mathrm{hPa}$ and the abscissa is latitude in degrees.

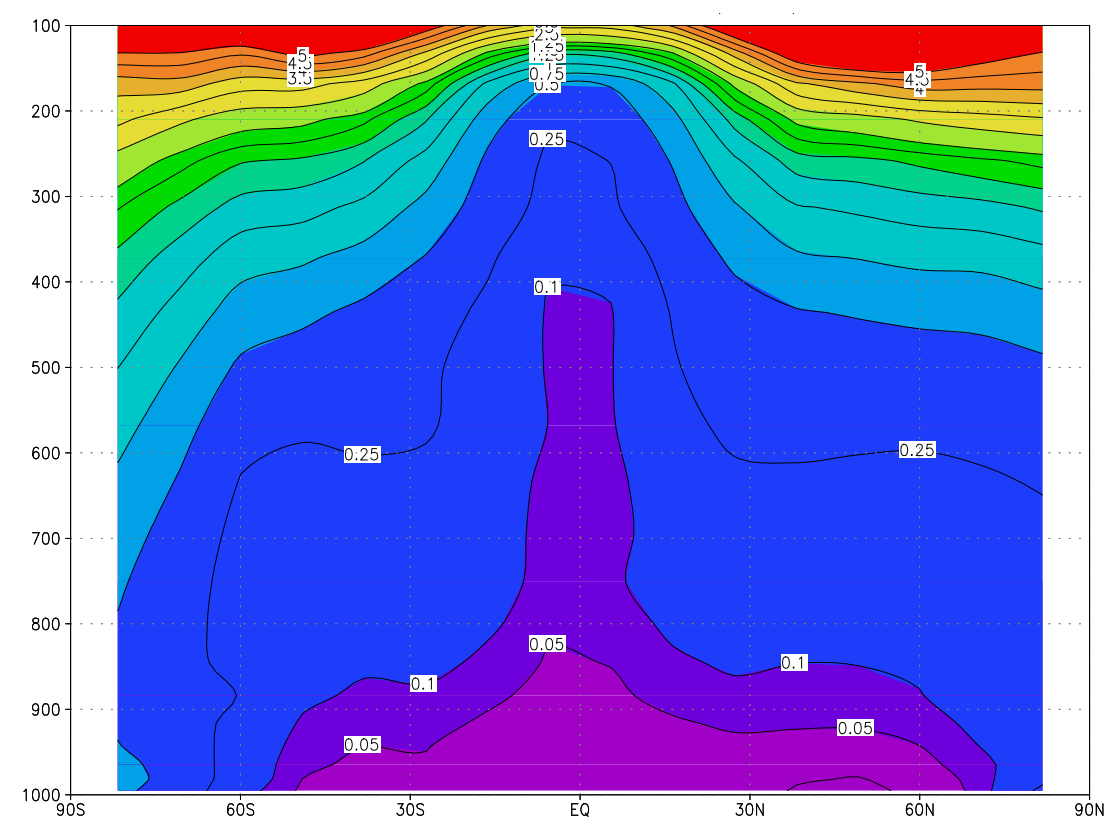

Fig. 4. Zonally and annually averaged mean of the BrO mixing ratio (in pmol mol ${ }^{-1}$ ) resulting from our source scenario "high lat". The ordinate is the $\sigma$-level multiplied by 1000 which is approximately the pressure in $\mathrm{hPa}$ and the abscissa is latitude in degrees. Note that $24 \mathrm{~h}$ averages are plotted. Seasalt aerosol is not explicitly included as a source therefore boundary layer values are lower limits.

to "high lat" with a smaller but discernable increase from the tropics to higher latitudes (see explanation below). In all scenarios $\mathrm{Br}_{\text {inorg }}$ mixing ratios increase with altitude (see below). Assuming photochemical steady state we calculated the lifetime of $\mathrm{Br}_{\text {inorg }}$ that is between 10 and 25 days for the free troposphere in case "high lat, fast recycling" (see Fig. 3). The influence of the recycling of bromine on aerosols on the $\mathrm{Br}_{\text {inorg }}$ lifetime is decreasing with altitude and is strongest below about $400 \mathrm{hPa}$. In case "fast recycling" the $\mathrm{Br}_{\text {inorg }}$ lifetime is about $20 \%$ to $130 \%$ higher than in case "slow 


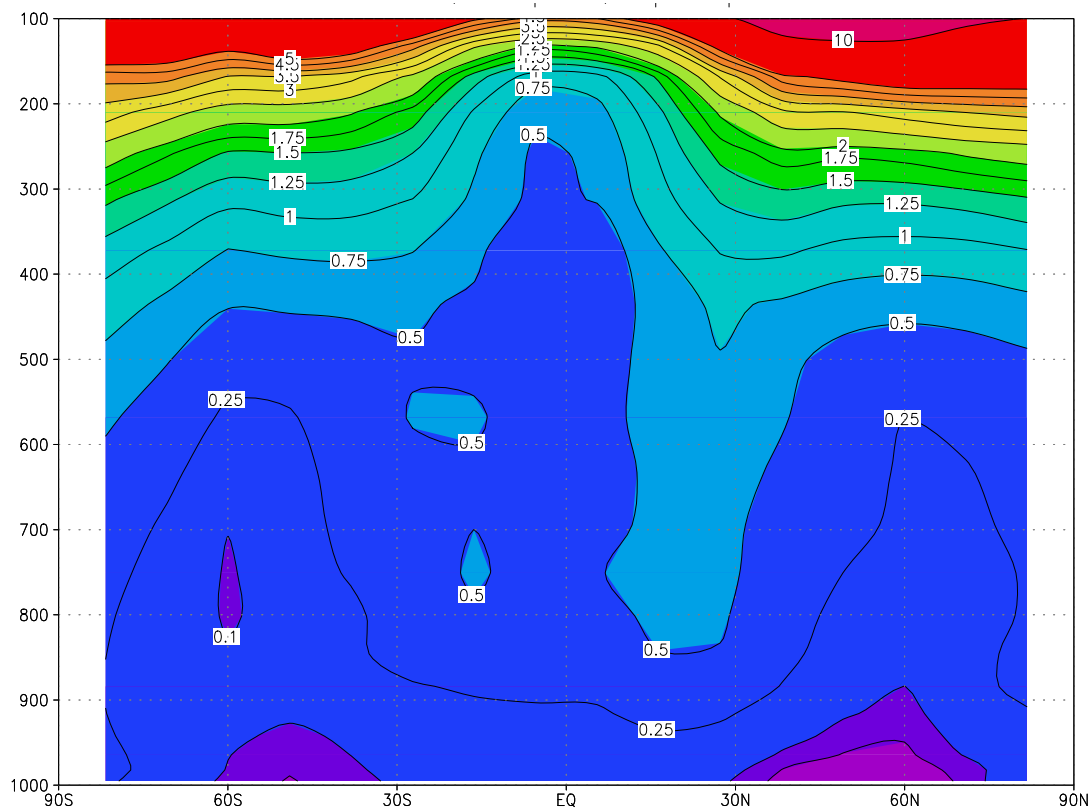

Fig. 5. Zonally and annually averaged mean of the BrO mixing ratio (in pmol mol ${ }^{-1}$ ) resulting from our source scenario "tropics". The ordinate is the $\sigma$-level multiplied by 1000 which is approximately the pressure in $\mathrm{hPa}$ and the abscissa is latitude in degrees. Note that $24 \mathrm{~h}$ averages are plotted. Seasalt aerosol is not explicitly included as a source therefore boundary layer values are lower limits.

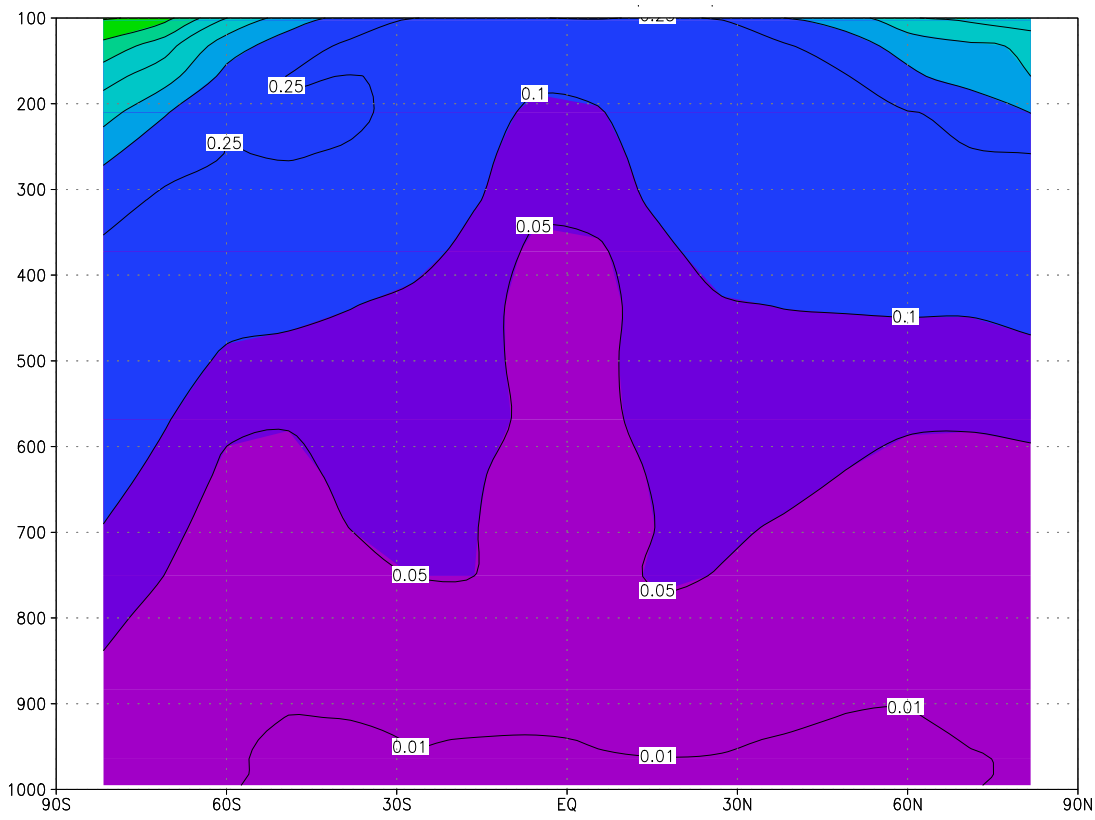

Fig. 6. Zonally and annually averaged mean of the BrO mixing ratio (in pmol mol ${ }^{-1}$ ) resulting from our source scenario "strat". The ordinate is the $\sigma$-level multiplied by 1000 which is approximately the pressure in $\mathrm{hPa}$ and the abscissa is latitude in degrees. Note that $24 \mathrm{~h}$ averages are plotted.

recycling" and even $50 \%$ to $230 \%$ higher than in case "no recycling".

The zonally averaged annual mean mixing ratio of $\mathrm{BrO}$ ( $24 \mathrm{~h}$ average) is less than $0.5 \mathrm{pmol} \mathrm{mol}^{-1}$ in all scenarios for most of the troposphere and reaches $2 \mathrm{pmol} \mathrm{mol}^{-1}$ only in the upper troposphere especially in scenario "tropics" (see Figs. 4, 5, and 6). It increases with altitude and southern latitude. The $\mathrm{BrO}$ distribution in the "const" and "tropics" 


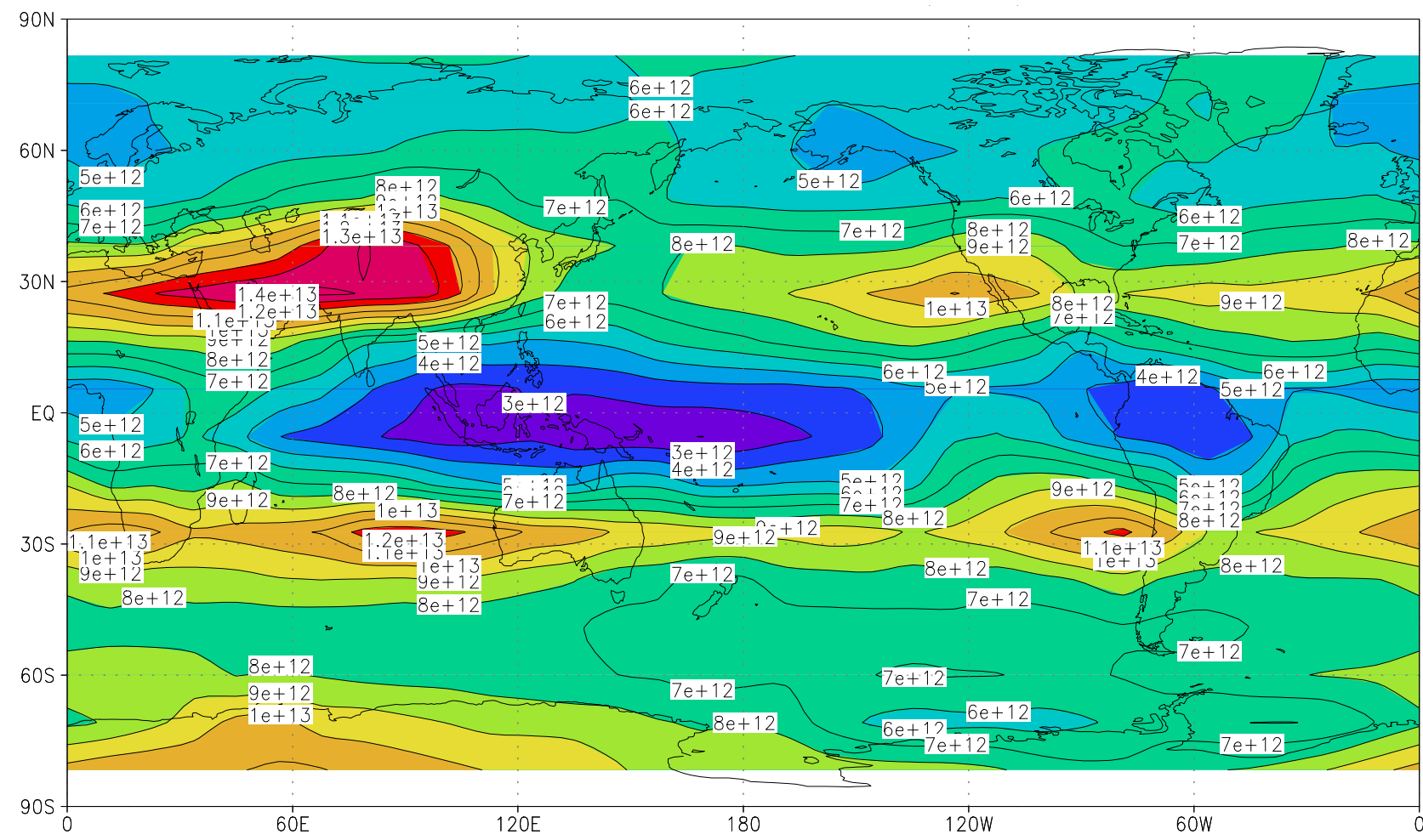

Fig. 7. Annually averaged tropospheric vertical column of $\mathrm{BrO}$ (in molec $\mathrm{cm}^{-2}$ ) for the scenario "high lat". We used the WMO definition for the determination of the tropopause. Note that $24 \mathrm{~h}$ averages are plotted. The ordinate is latitude in degrees and the abscissa is longitude in degrees.

runs is latitudinally more uniform than that of case "high lat". This latitudinal pattern in the scenario "high lat" follows roughly the trend in $\mathrm{Br}_{\text {inorg }}$ but the zonally averaged ratio of $\mathrm{BrO}$ to $\mathrm{Br}_{\text {inorg }}$ ( $24 \mathrm{~h}$ average) also increases with altitude and with latitude (in all runs) with values of 0.05 near the surface increasing to 0.3 at the top of the troposphere (see Fig. 2). This is mainly due to an increase in solar radiation and therefore shorter lifetimes of $\mathrm{HOBr}$ and $\mathrm{BrNO}_{3}$. This trend is present in all scenarios but the increase with altitude is faster in runs with higher recycling rates because the faster recycling increases the lifetime of $\mathrm{Br}_{\text {inorg. }}$. Another factor is the increase in $\mathrm{Br}_{2}: \mathrm{Br}_{\text {inorg }}$ and a decrease in $\mathrm{HOBr}: \mathrm{Br}_{\text {inorg }}$ with altitude which increases the relative contribution of $\mathrm{BrO}$ because the photolysis rate for $\mathrm{Br}_{2}$ is greater than that for $\mathrm{HOBr}$ and increases $\mathrm{Br}_{\text {inorg }}$ with altitude by a reduction in the washout of $\mathrm{Br}_{\text {inorg }}$ because of differences in solubility of $\mathrm{Br}_{2}$ and $\mathrm{HOBr}$.

It has been shown with a one-dimensional model (von Glasow et al., 2002a) that the difference of the wavelength dependence of $\mathrm{O}_{3} \longrightarrow \mathrm{O}\left({ }^{1} \mathrm{D}\right)$ and $\mathrm{Br}_{2}$ photolysis leads to a diurnal variation of $\mathrm{BrO}$ with small morning and afternoon peaks if $\mathrm{HO}_{2}$ is the main sink, and a broad diurnal variation with a small peak at noon if $\mathrm{NO}_{2}$ is the main sink. These two types of diurnal variations are found in our 3D model results as well.
Figures 7 and 8 show the vertically integrated tropospheric column density (using the WMO definition of the tropopause) of $\mathrm{BrO}$ for the scenarios "high lat" and "tropics", respectively, with values of about $0.5-1 \times 10^{13}$ molec $\mathrm{cm}^{-2}$ in the tropics and up to $2.4 \times 10^{13} \mathrm{molec} \mathrm{cm}^{-2}$ in higher latitudes. The large gradient in the tropopause height in the subtropics leads to a maximum in the vertical column of $\mathrm{BrO}$ in that region. The maximum values are reached only in the subtropics, whereas in most parts of the troposphere the model $\mathrm{BrO}$ vertical columns are somewhat smaller than the tropospheric vertical $\mathrm{BrO}$ columns of $<1$ $3 \times 10^{13}$ molec cm$^{-2}$ that were derived from comparisons of satellite, balloon, and ground measurements (Pundt et al., 2000; Van Roozendael et al., 2002; Richter et al., 2002). For this reason, the results presented here should be regarded as a conservative estimate of the overall effects of bromine chemistry in the free troposphere and, as mentioned before, a lower limit for the boundary layer.

The inorganic bromine levels in scenario "strat" are by far too small to explain the observed tropospheric vertical columns which in this run are only $0.5-2 \times 10^{12}$ molec $\mathrm{cm}^{-2}$. The annually and zonally averaged $24 \mathrm{~h}$ mixing ratios of $\mathrm{BrO}$ are less then $0.25 \mathrm{pmol} \mathrm{mol}^{-1}$ in the troposphere (see Fig. 6). This implies that downward flux of stratospheric inorganic bromine and decomposition of $\mathrm{CH}_{3} \mathrm{Br}$ are not sufficient as 


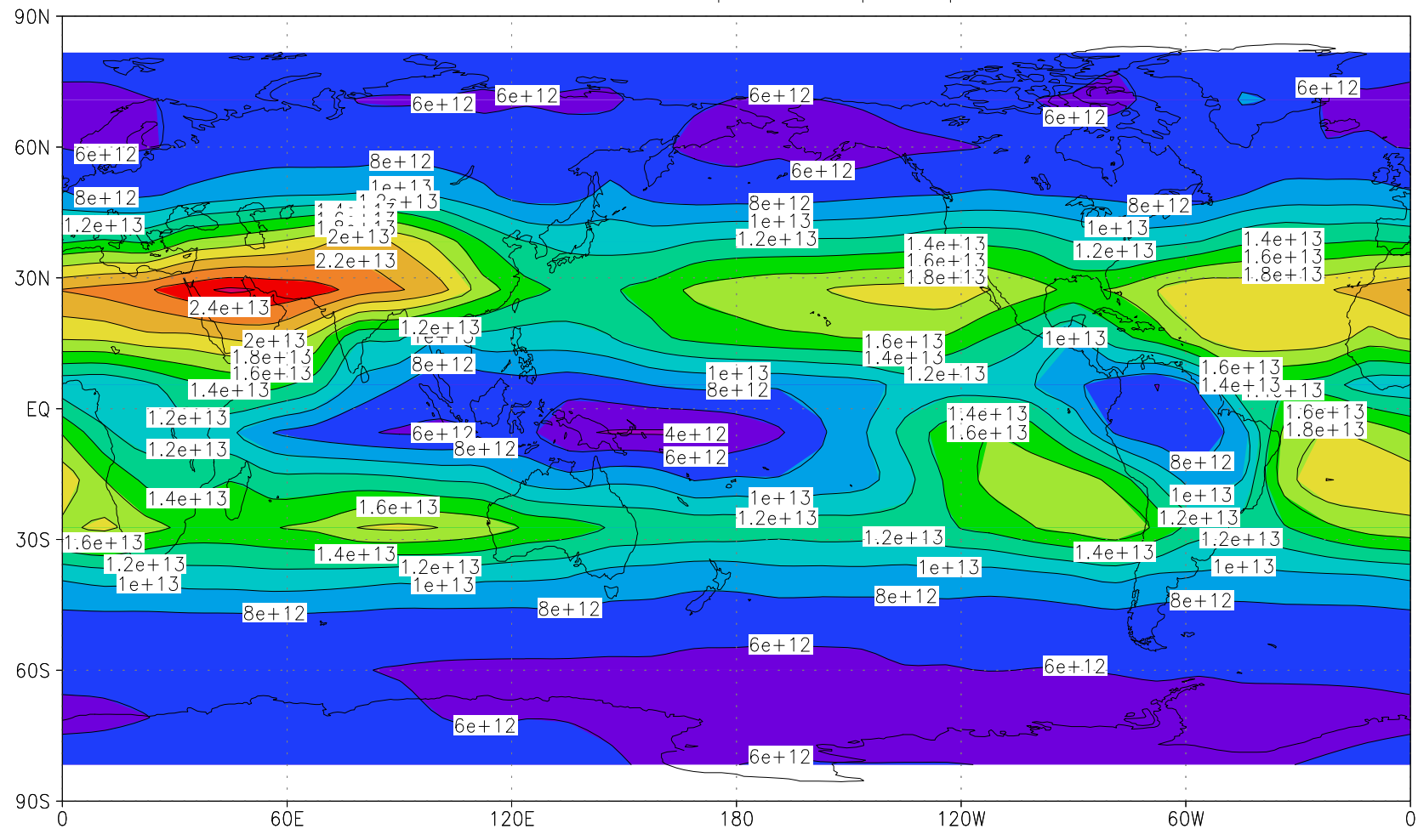

Fig. 8. Annually averaged tropospheric vertical column of $\mathrm{BrO}$ (in molec $\mathrm{cm}^{-2}$ ) for the scenario "tropics". We used the WMO definition for the determination of the tropopause. Note that $24 \mathrm{~h}$ averages are plotted. The ordinate is latitude in degrees and the abscissa is longitude in degrees.

source for free tropospheric inorganic bromine. They would either have to be increased by about a factor of 5-7 or additional sources of reactive bromine have to be active.

\subsection{Effect on ozone}

The runs with bromine levels that reproduce the observations best lead to a notable decrease in $\mathrm{O}_{3}$. Even in the runs with smallest $\mathrm{BrO}$ mixing ratios of only a few tenths of a pmol mol ${ }^{-1}$ (scenario "high lat, no recycling" and "strat", see Fig. 11) the annually and zonally averaged difference to the run without bromine chemistry is of the order of several percent. In the case "high lat, slow recycling" with higher BrO mixing ratios it is already $5-10 \%$ throughout the troposphere, whereas in the run with $\mathrm{BrO}$ mixing ratios that are closest to the values deduced from satellite and balloon observations ("high lat") the difference in zonal mean $\mathrm{O}_{3}$ mixing ratio compared to the run without bromine chemistry is 6-18\% (see Fig. 9). Maximum regional differences are up to $40 \%$ in the austral summer high latitudes. These numbers imply that there might be an important $\mathrm{O}_{3}$ destruction mechanism in the troposphere that has been neglected so far.

Even though the mixing ratio and distribution of $\mathrm{Br}_{\text {inorg }}$ and $\mathrm{BrO}$ differ among the different scenarios, the overall vertical and latitudinal distribution of the effect on $\mathrm{O}_{3}$ remains
Table 3. Tropospheric burdens of $\mathrm{O}_{3}$ and DMS in $\mathrm{Tg}$.

\begin{tabular}{lll}
\hline scenario & $\mathrm{O}_{3}$ burden & DMS burden \\
\hline high lat & 157.0 & 4.612 \\
tropics & 147.5 & 4.787 \\
strat & 172.2 & 5.848 \\
nohal & 174.6 & 6.249 \\
\hline
\end{tabular}

similar in all discussed runs, namely that $\mathrm{O}_{3}$ destruction is strongest in the FT of the southern hemisphere. It is smallest near the ground in northern mid latitudes. This is due to smaller sensitivities of the photochemistry to perturbations when high $\mathrm{O}_{3}$ sources and sinks are present as is the case in the polluted regions compared to a greater sensitivity in the more pristine FT in the southern hemisphere where photochemical sources and sinks for $\mathrm{O}_{3}$ are smaller. In scenario "tropics" the maximum of the difference in zonally averaged $\mathrm{O}_{3}$ (up to $20 \%$ less $\mathrm{O}_{3}$ compared to a run without bromine chemistry, see Fig. 10) is shifted from higher latitudes towards $50-30^{\circ} \mathrm{S}$ and strongest in magnitude compared to all other presented cases. Nevertheless, even in this case the main pattern with highest differences in $\mathrm{O}_{3}$ in the southern FT remains the same. 


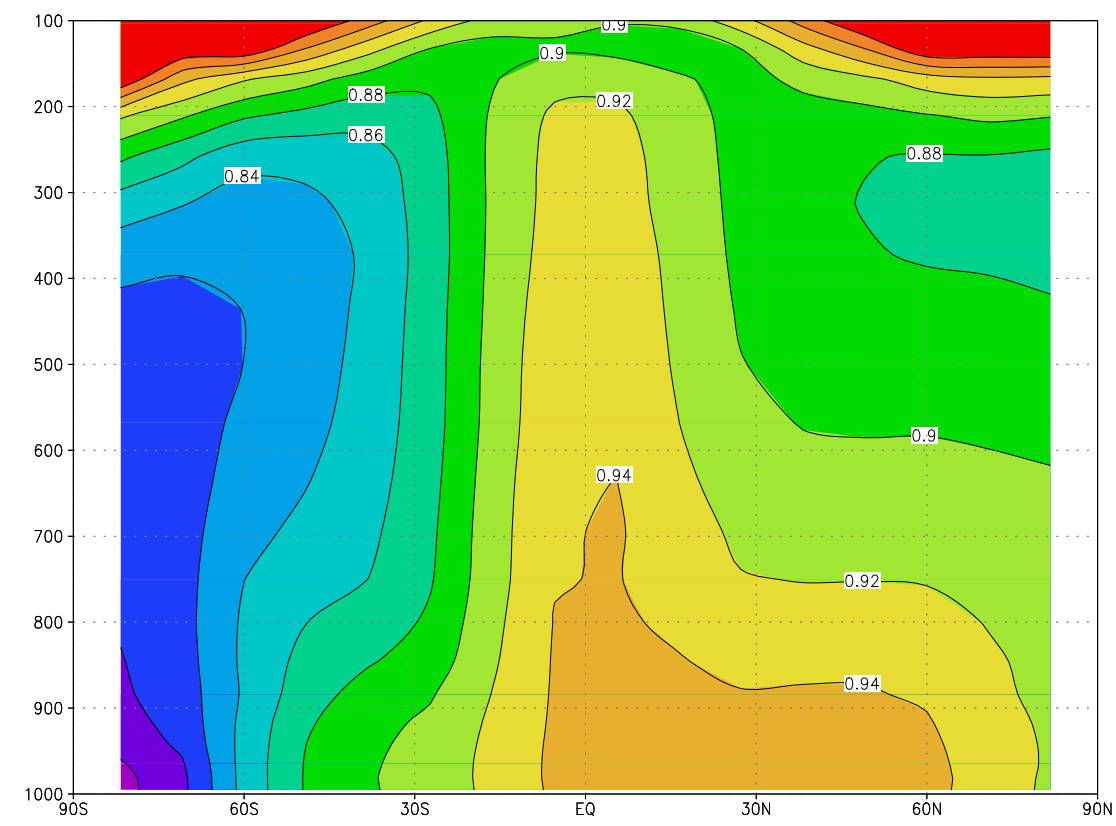

Fig. 9. Ratio of $\mathrm{O}_{3}$ in scenario "high lat" to $\mathrm{O}_{3}$ in scenario "no hal". The numbers are zonally and annually averaged. The ordinate is the $\sigma$-level multiplied by 1000 which is approximately the pressure in $\mathrm{hPa}$ and the abscissa is latitude in degrees. Note that $24 \mathrm{~h}$ averages are plotted.

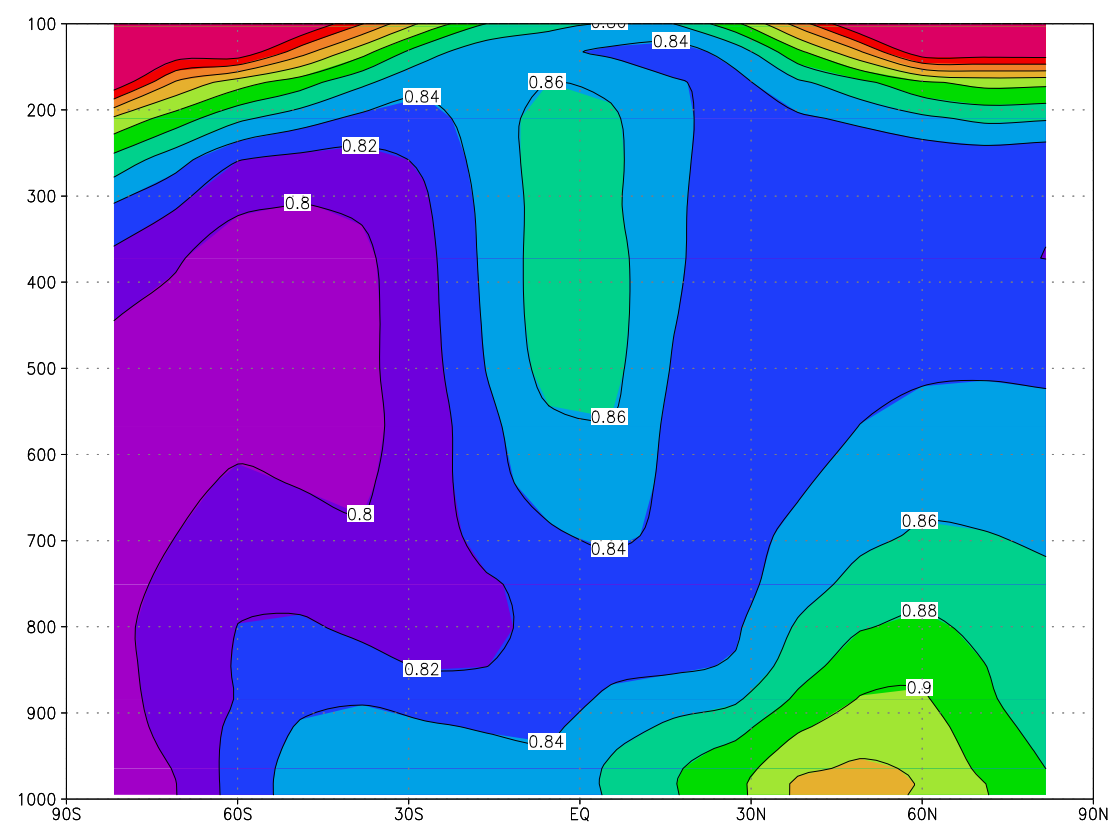

Fig. 10. Ratio of $\mathrm{O}_{3}$ in scenario "tropics" to $\mathrm{O}_{3}$ in scenario "no hal". The numbers are zonally and annually averaged. The ordinate is the $\sigma$-level multiplied by 1000 which is approximately the pressure in $\mathrm{hPa}$ and the abscissa is latitude in degrees. Note that $24 \mathrm{~h}$ averages are plotted.

Compared to the run without bromine chemistry, the tropospheric burden of $\mathrm{O}_{3}$ (see Table 3 ) is reduced in scenarios "high lat", "tropics", and "strat" by $10 \%, 15 \%$, and 3\%, respectively. The ozone loss by reaction (Br7) equals approximately $28 \%$ of the dry deposition in run "high lat".

\subsection{Effect on $\mathrm{HO}_{\mathrm{x}}$}

The reaction $\mathrm{BrO}+\mathrm{HO}_{2} \longrightarrow \mathrm{HOBr}$ destroys $\mathrm{HO}_{2}$ and the subsequent photolysis of $\mathrm{HOBr}$ releases $\mathrm{OH}$. Both processes are acting in the direction of an increase of the $\mathrm{OH}$ to $\mathrm{HO}_{2}$ 


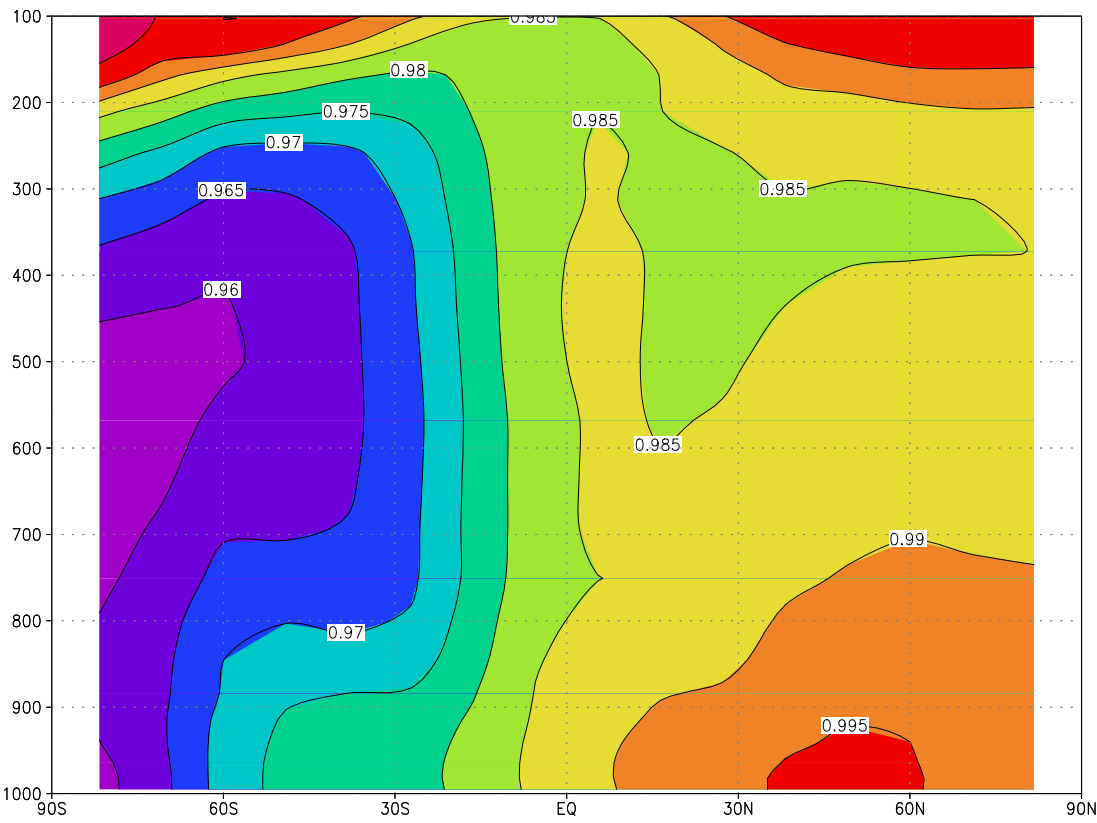

Fig. 11. Ratio of $\mathrm{O}_{3}$ in scenario "strat" to $\mathrm{O}_{3}$ in scenario "no hal". The numbers are zonally and annually averaged. The ordinate is the $\sigma$-level multiplied by 1000 which is approximately the pressure in $\mathrm{hPa}$ and the abscissa is latitude in degrees. Note that $24 \mathrm{~h}$ averages are plotted.

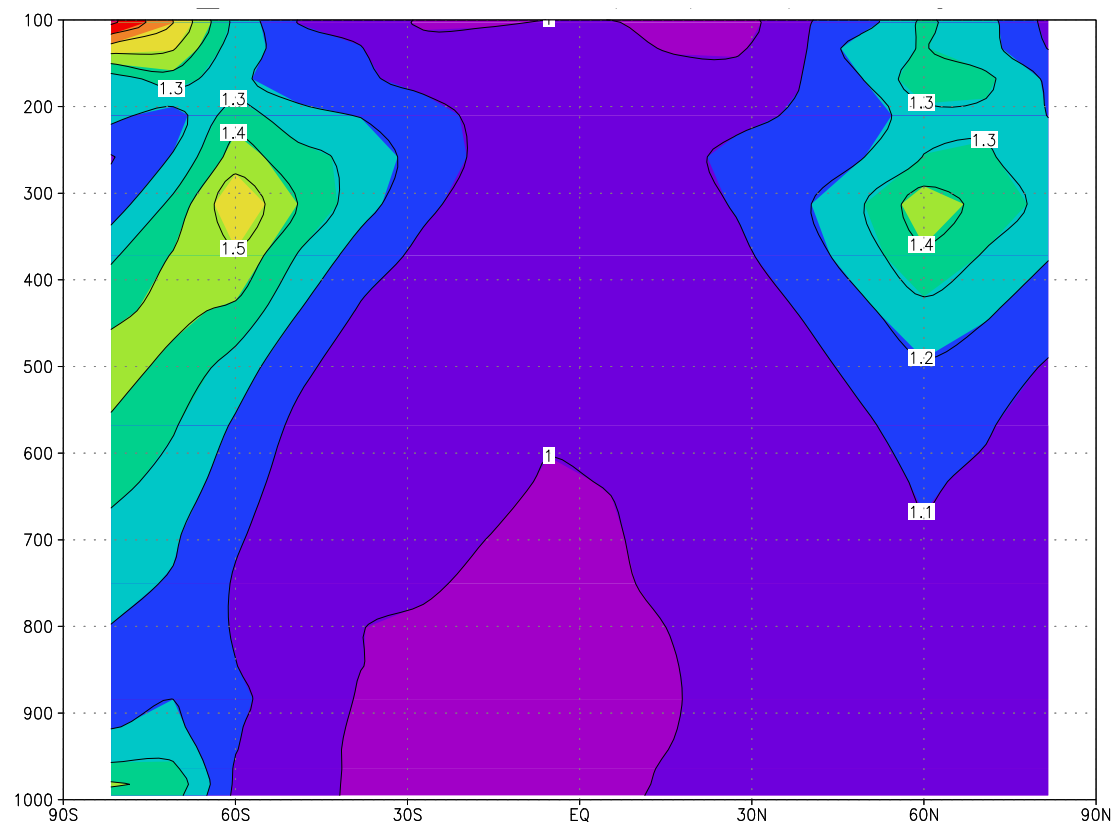

Fig. 12. Ratio of $\mathrm{OH}: \mathrm{HO}_{2}$ in scenario "high lat" to $\mathrm{OH}: \mathrm{HO}_{2}$ in scenario "no hal". The numbers are zonally and annually averaged. The ordinate is the $\sigma$-level multiplied by 1000 which is approximately the pressure in $\mathrm{hPa}$ and the abscissa is latitude in degrees. Note that $24 \mathrm{~h}$ averages are plotted.

ratio. This shift is highest in the upper FT with up to 50\% and $40 \%$ in the southern and northern high latitudes, respectively, in the scenario "high lat" (compared to the ratio in the run without bromine, see Fig. 12). In mid and low latitudes this effect is less than $10 \%$. As mentioned in the introduction, this shift implies less $\mathrm{O}_{3}$ production because in the reactions

$$
\begin{aligned}
& \mathrm{BrO}+\mathrm{HO}_{2} \longrightarrow \mathrm{HOBr}+\mathrm{O}_{2} \\
& \mathrm{HOBr}+\mathrm{h} v \longrightarrow \mathrm{OH}+\mathrm{Br}
\end{aligned}
$$


$\mathrm{HO}_{2}$ gets cycled back to $\mathrm{OH}$ without oxidizing $\mathrm{NO}$ to $\mathrm{NO}_{2}$. Furthermore reaction $\mathrm{Br} 7$ destroys $\mathrm{O}_{\mathrm{x}}$ because $\mathrm{BrO}$ is part of the odd oxygen family. The decrease in $\mathrm{HO}_{2}$ concentrations compared to scenario "no hal" is up to $10 \%$ in runs "high lat" and "tropics" with the strongest effect in the free troposphere. In the run "high lat" it is most pronounced at high latitudes whereas it is more uniform with latitude in the run "tropics".

The $\mathrm{OH}$ concentration increases in the upper FT by more than $20 \%$ compared to the run without bromine chemistry but this is contrasted by small relative decreases in $\mathrm{OH}$ in the tropics. Most $\mathrm{OH}$, however, is located in the tropics where the reduction in $\mathrm{O}_{3}$ is strong enough to reduce $\mathrm{OH}$, so that the change in global mean $\mathrm{OH}$ concentrations (calculated weighted with $\mathrm{CH}_{4}$ as well as with air mass after Lawrence et al. (2001)) is only for the "tropics" scenario on the order of $1-2 \%$. For the other runs it is virtually indiscernible from scenario "no hal". The lifetime of $\mathrm{CH}_{4}$ is almost unchanged compared to "no hal" in all runs but "tropics" where it increased from 9.62 years to 9.83 years, again only $2 \%$ so that these effects are negligible.

$\mathrm{H}_{2} \mathrm{O}_{2}$ decreases with latitude and altitude compared to the run without bromine chemistry (see Fig. 13). This is caused by the decrease in $\mathrm{HO}_{2}$ which is the main precursor for $\mathrm{H}_{2} \mathrm{O}_{2}$. The decrease in $\mathrm{H}_{2} \mathrm{O}_{2}$ in the tropics is a few percent in scenario "high lat" and 5-10\% in scenario "tropics" but more than $20 \%$ in the high latitude free troposphere. The reduction is therefore larger than that in $\mathrm{HO}_{2}$, because the formation rate of $\mathrm{H}_{2} \mathrm{O}_{2}$ in reaction

$$
\mathrm{HO}_{2}+\mathrm{HO}_{2} \longrightarrow \mathrm{H}_{2} \mathrm{O}_{2}+\mathrm{O}_{2}
$$

is quadratic in $\mathrm{HO}_{2}$. The decrease in $\mathrm{H}_{2} \mathrm{O}_{2}$ can be of importance for atmospheric chemistry because the gas phase is the main source for aqueous $\mathrm{H}_{2} \mathrm{O}_{2}$ which is the most important oxidant for $\mathrm{S}(\mathrm{IV})$ to $\mathrm{S}(\mathrm{VI})$ in the aqueous phase. A reduction in $\mathrm{H}_{2} \mathrm{O}_{2}$ would reduce the formation rates of particulate sulfate which, however, can possibly be compensated by $\mathrm{HOBr}$ (and $\mathrm{HOCl}$ ) as aqueous phase oxidants as explained e.g. in von Glasow and Crutzen (2004).

\subsection{Effect on nitrogen oxides}

The runs including bromine chemistry also show changes in the $\mathrm{NO}_{\mathrm{x}}$ mixing ratios in mid and high latitudes and especially in the FT. In the scenario "high lat" $\mathrm{NO}_{\mathrm{x}}$ concentrations are up to $25 \%$ smaller than in the run without bromine chemistry. In the lower troposphere, especially in the tropics, $\mathrm{NO}_{\mathrm{x}}$ increases by a few percent. These changes are approximately correlated with changes in $\mathrm{HO}_{2}$ and anticorrelated with changes in peroxy acetyl nitrate (PAN) and $\mathrm{OH}$. This is caused by an increase in the formation of PAN from the peroxy acetyl (PA) radical which is caused by a decrease in $\mathrm{HO}_{2}$ that destroys PA.

A decrease in $\mathrm{NO}_{\mathrm{x}}$ concentrations reduces the photochemical production of $\mathrm{O}_{3}$. This highlights that the difference in
$\mathrm{O}_{3}$ in our model runs is a combination of increased $\mathrm{O}_{3}$ destruction by bromine and reduced $\mathrm{O}_{3}$ production due to less $\mathrm{NO}_{\mathrm{x}}$ (indirectly caused by bromine) stressing the importance to consider all elements of the chemical system.

As already mentioned in the introduction, the reaction $\mathrm{BrO}+\mathrm{NO} \longrightarrow \mathrm{Br}+\mathrm{NO}_{2}$ reduces the production rate of $\mathrm{O}_{3}$ by oxidizing $\mathrm{NO}$ to $\mathrm{NO}_{2}$ without changing the sum of odd oxygen. In the model results, however, the ratio of NO to $\mathrm{NO}_{2}$ decreases only in the uppermost troposphere in high latitudes and in the stratosphere. In most of the troposphere the ratio increases compared to a run without bromine chemistry. (see Fig. 14). This is caused by decreases in the $\mathrm{O}_{3}$ and $\mathrm{HO}_{2}$ concentrations which are crucial for the steady state ratio of $\mathrm{NO}$ to $\mathrm{NO}_{2}$ and which cannot be compensated by the presence of less than $2 \mathrm{pmol} \mathrm{mol}^{-1} \mathrm{BrO}$ (see e.g. Brasseur et al. (1999)):

$$
\begin{aligned}
\frac{[N O]}{\left[N O_{2}\right]} & =j\left(\mathrm{NO}_{2}\right) \times\left(k_{\mathrm{NO}+\mathrm{O}_{3}}\left[\mathrm{O}_{3}\right]+k_{\mathrm{HO}_{2}+\mathrm{NO}}\left[\mathrm{HO}_{2}\right]\right. \\
& \left.+k_{\mathrm{CH}_{3} \mathrm{O}_{2}+\mathrm{NO}}\left[\mathrm{CH}_{3} \mathrm{O}_{2}\right]+k_{\mathrm{BrO}+\mathrm{NO}}[\mathrm{BrO}]\right)^{-1}
\end{aligned}
$$

The ratio of $\mathrm{BrNO}_{3}$ to $\mathrm{Br}_{\mathrm{x}}$ is highest in northern mid latitudes near the ground, the highest $\mathrm{BrNO}_{3}$ mixing ratios are found near the tropopause, they are less than $0.5 \mathrm{pmol} \mathrm{mol}^{-1}$ in most of troposphere in all runs except for "tropics" where they can reach up to $1 \mathrm{pmol} \mathrm{mol}^{-1}$ in the tropical mid troposphere. The contribution of $\mathrm{BrNO}_{3}$ to $\mathrm{NO}_{\mathrm{y}}$ is less than $0.5 \%$. The heterogenous reaction of $\mathrm{BrNO}_{3}$ produces particulate $\mathrm{NO}_{3}^{-}$(see Sander et al. (1999)) and therefore contributes to the loss of $\mathrm{NO}_{\mathrm{x}}$. This $\mathrm{NO}_{\mathrm{x}}$ loss by the heterogeneous reaction of $\mathrm{BrNO}_{3}$ is about 4.5 and $10 \%$ of the $\mathrm{NO}_{\mathrm{x}}$ loss by reaction $\mathrm{NO}_{2}+\mathrm{OH} \longrightarrow \mathrm{HNO}_{3}$ in the runs "high lat" and "tropics", respectively.

\subsection{Effect on DMS}

Another very important result of our study is the impact of $\mathrm{BrO}$ on DMS chemistry with a strong reduction of its mixing ratio and a drastic change in its oxidation pathways. DMS is emitted by marine organisms and is the main natural source for reactive sulfur in the marine atmosphere. The main sinks of DMS are usually thought to be reaction with $\mathrm{OH}$ and $\mathrm{NO}_{3}$, however, the reaction of DMS with $\mathrm{BrO}$ can be a significant sink as well (Toumi, 1994). In the cloudy MBL an increase in DMS oxidation by BrO leads to the production of more DMSO which is rapidly taken up by clouds. This reduces the DMS to $\mathrm{SO}_{2}$ conversion efficiency, which is indicative of the potential for formation of new cloud condensation nuclei (CCN), but increases the size of already present $\mathrm{CCN}$ by the formation of particulate sulfur (methyl sulfonic acid and sulfate) (von Glasow et al., 2002b; von Glasow and Crutzen, 2004). This and other feedbacks like increased drizzle formation due to larger CCN would lead to a reduction in cloud 


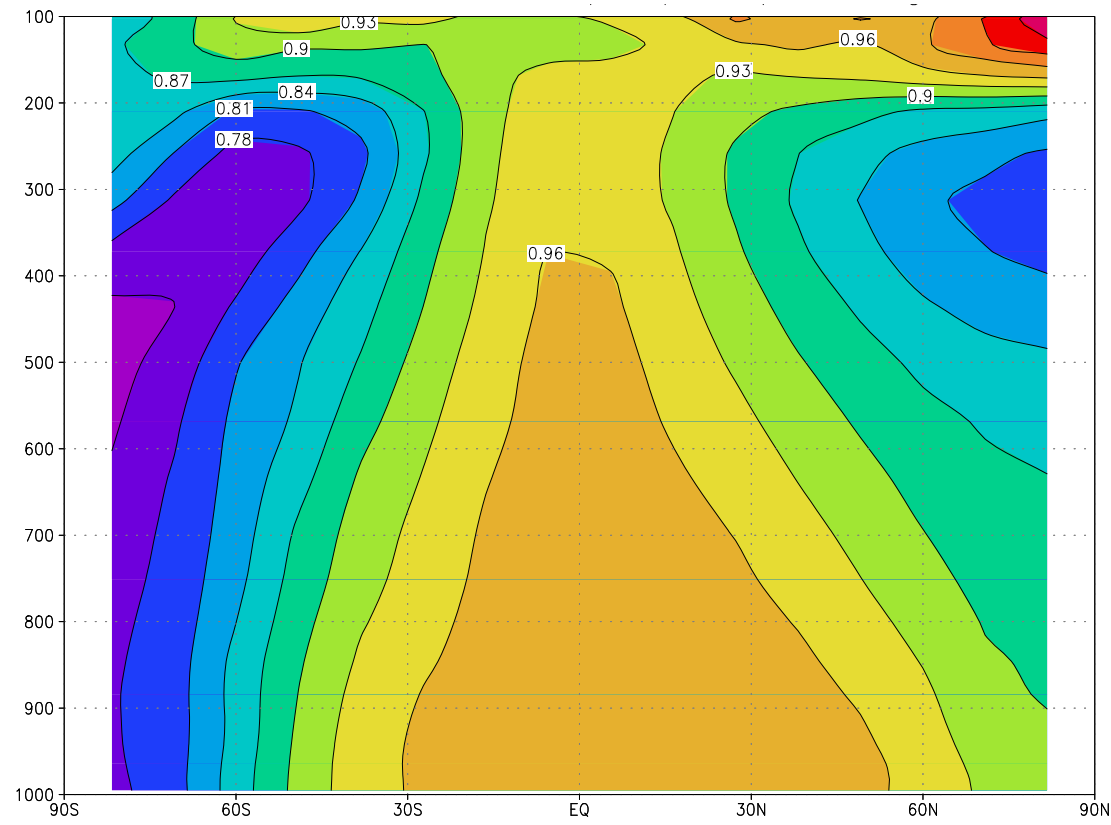

Fig. 13. Ratio of $\mathrm{H}_{2} \mathrm{O}_{2}$ in scenario "high lat" to $\mathrm{H}_{2} \mathrm{O}_{2}$ in scenario "no hal". The numbers are zonally and annually averaged. The ordinate is the $\sigma$-level multiplied by 1000 which is approximately the pressure in $\mathrm{hPa}$ and the abscissa is latitude in degrees. Note that $24 \mathrm{~h}$ averages are plotted.

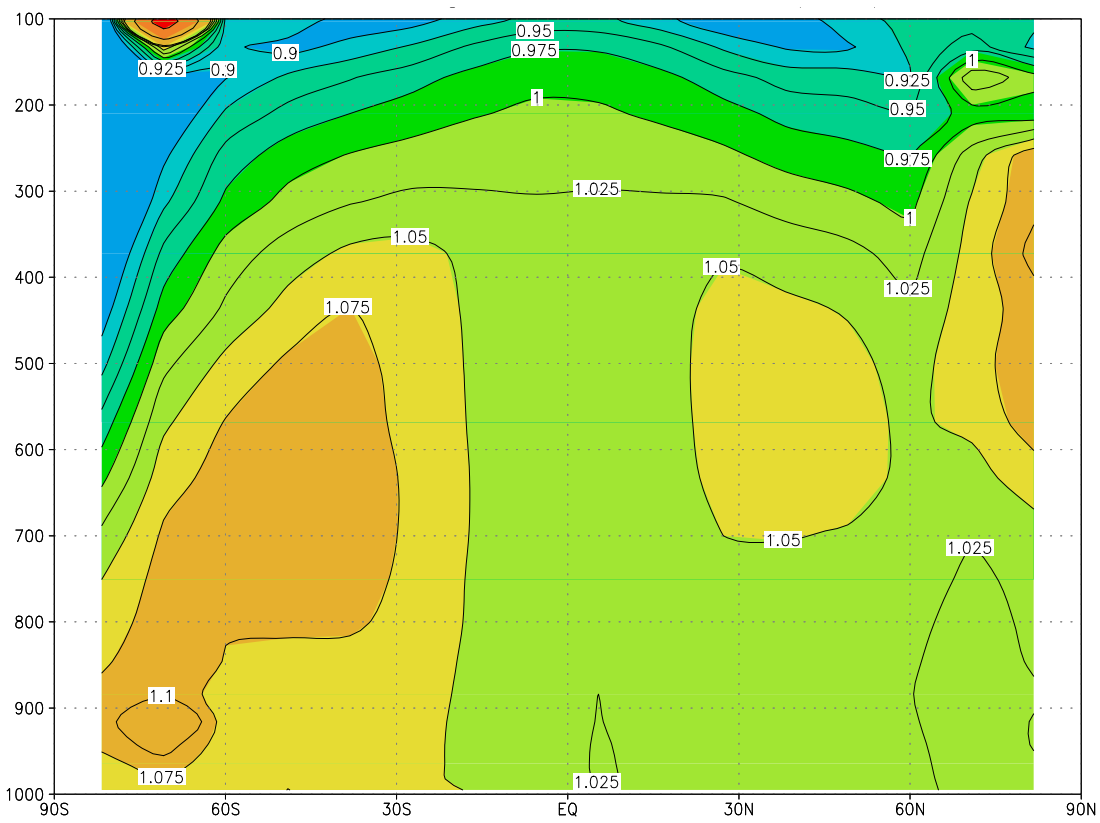

Fig. 14. Ratio of $\mathrm{NO}: \mathrm{NO}_{2}$ in scenario "high lat" to $\mathrm{NO}: \mathrm{NO}_{2}$ in scenario "no hal". The numbers are zonally and annually averaged. The ordinate is the $\sigma$-level multiplied by 1000 which is approximately the pressure in $\mathrm{hPa}$ and the abscissa is latitude in degrees. Note that $24 \mathrm{~h}$ averages are plotted.

albedo. Boucher et al. (2003) performed a sensitivity study with a global model assuming a constant daytime $\mathrm{BrO}$ mixing ratio of $1 \mathrm{pmol} \mathrm{mol}^{-1}$ in the MBL and found a reduction of the tropospheric DMS burden by about $30 \%$.
In our model runs the tropospheric DMS burden is reduced due to the reaction DMS + $\mathrm{BrO}$ by $26 \%, 23 \%$, and $6 \%$ in scenarios "high lat", "tropics", respectively (see Table 3). The vertical columns of DMS mixing ratios (dominated by the MBL) are reduced by $3-30 \%$ in run "high lat, 


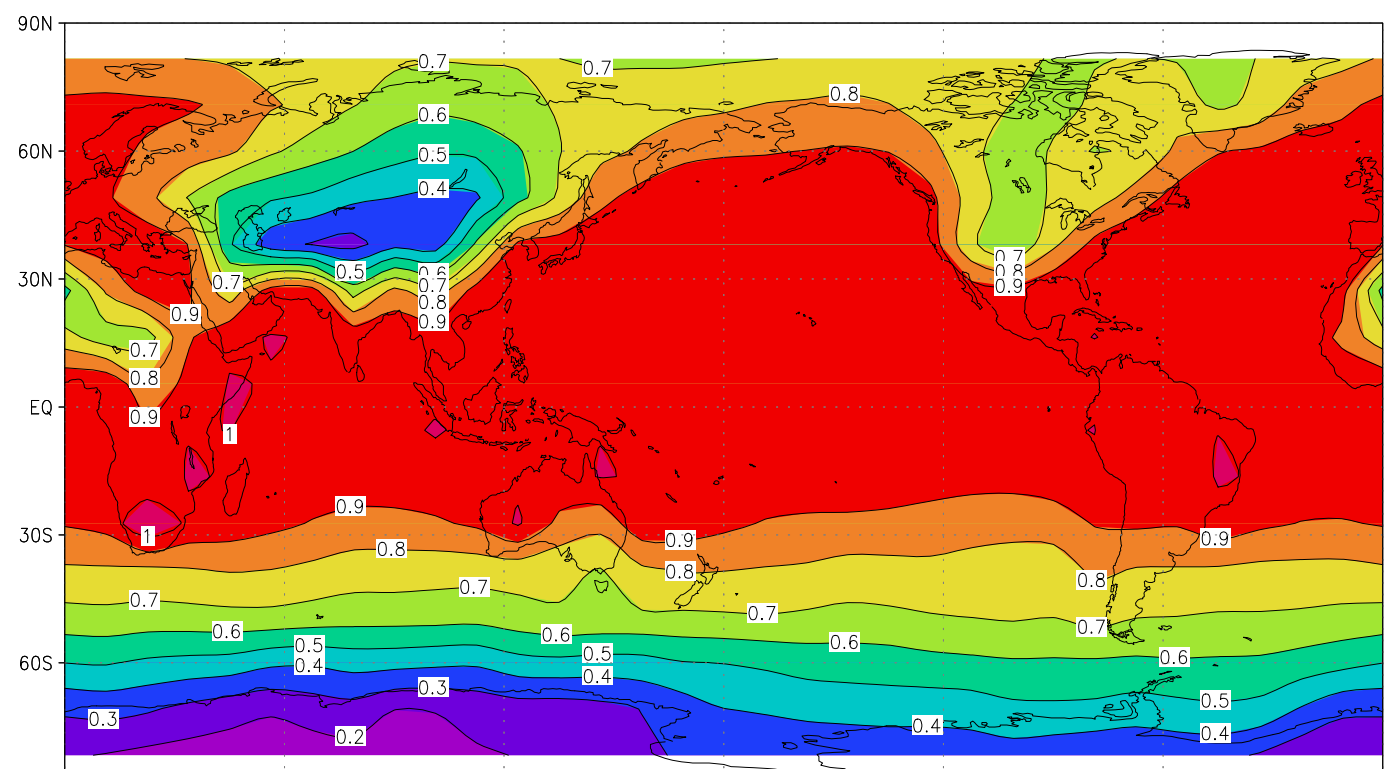

Fig. 15. Ratio of the vertical column of DMS for the scenario "high lat" to scenario "no hal" (annually averaged). The ordinate is latitude in degrees and the abscissa is longitude in degrees. Seasalt aerosol is not explicitly included as a source for BrO therefore the reductions in DMS are lower limits.

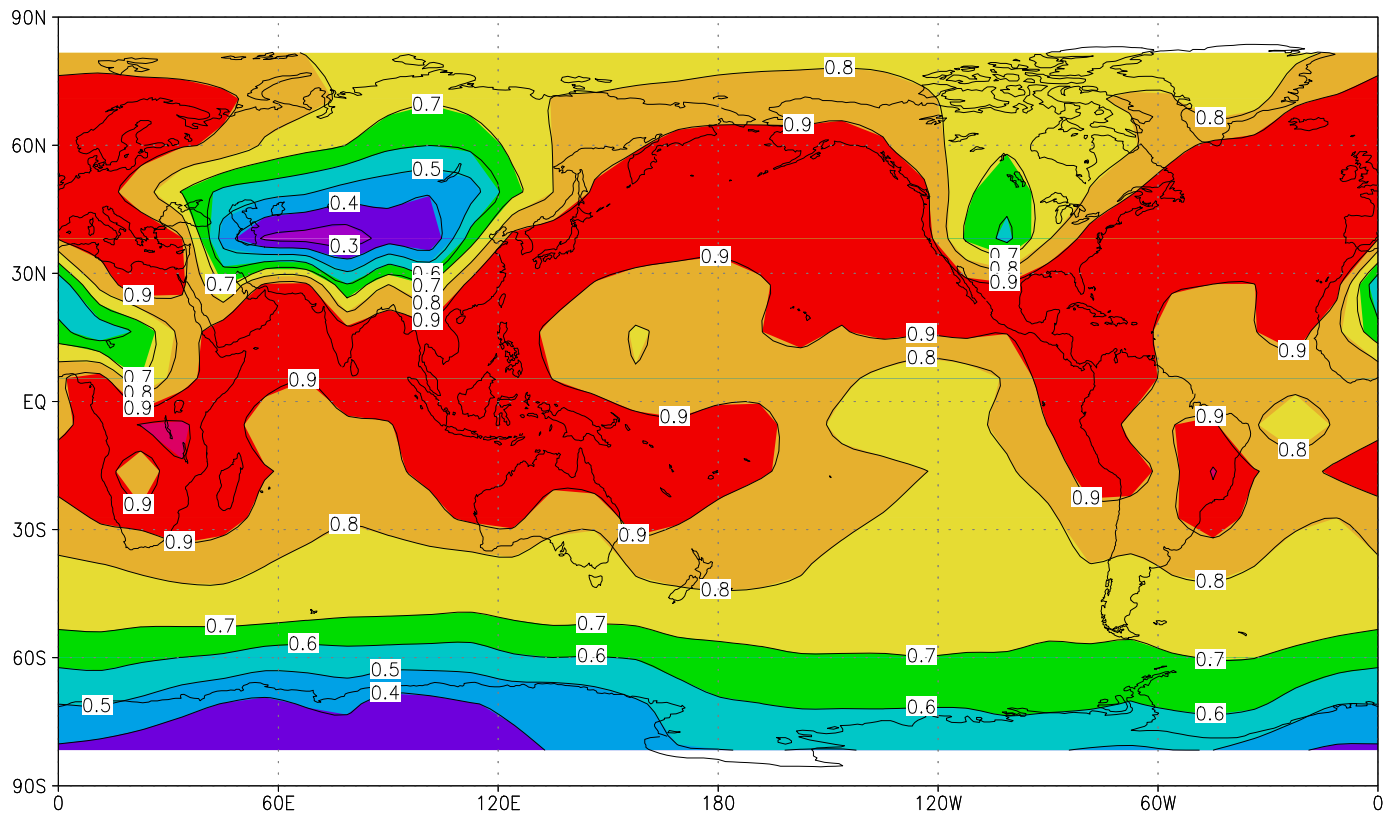

Fig. 16. Ratio of the vertical column of DMS for the scenario "tropics" to scenario "no hal" (annually averaged). The ordinate is latitude in degrees and the abscissa is longitude in degrees. Seasalt aerosol is not explicitly included as a source for BrO therefore the reductions in DMS are lower limits.

no recycling" with the smaller values close to the equator. In runs "high lat" and "tropics" the difference to "no hal" in many regions is more than $10 \%$, and it is especially high in the regions with highest DMS fluxes and mixing ratios, the Southern Ocean (Kettle et al., 1999) as evident from
Figs. 15 and 16. The spatial distribution of the DMS differences in the model is caused by a latitudinal gradient in $\mathrm{BrO}$ with annually averaged $24 \mathrm{~h}$ mean mixing ratios in the boundary layer of $0.05(0.4) \mathrm{pmol} \mathrm{mol}^{-1}$ in the tropics and $0.3(0.1) \mathrm{pmol} \mathrm{mol}^{-1}$ in high latitudes for scenario "high lat 
("tropics"). Note that DMS mixing ratios are highest in the MBL where our bromine source approach will likely underestimate $\mathrm{BrO}$ mixing ratios because we did not include explicitly sea salt aerosol as a source for reactive halogens, so these results are lower limits. The main conclusion from this result is that the global importance of bromine chemistry for the oxidation of DMS should be investigated in more detail.

The main difference of our study to that by Boucher et al. (2003) is, that they assumed a constant daytime $\mathrm{BrO}$ mixing ratio of $1 \mathrm{pmol} \mathrm{mol}^{-1}$ everywhere in the MBL whereas in our model runs the $24 \mathrm{~h}$ average mixing ratio of $\mathrm{BrO}$ in the MBL is only $0.1-0.3 \mathrm{pmol} \mathrm{mol}^{-1}$ in "high lat" and less than $0.05 \mathrm{pmol} \mathrm{mol}^{-1}$ in runs "high lat, no recycling" and "strat". Again we want to stress that these $\mathrm{BrO}$ mixing ratios have to be regarded as lower limits.

The previously discussed increases in DMS oxidation, the shift in its oxidation products, and the changes in resulting new particle formation and growth of existing aerosol particles have the potential to dramatically alter our understanding of the DMS - CCN - climate connection. Moreover, some estimates of the DMS flux from the ocean rely on a comparison with atmospheric models to calculate the photochemical loss rate of DMS without taking oxidation by $\mathrm{BrO}$ into account, implying that DMS fluxes from these studies might be underestimating the real fluxes (see also discussion in von Glasow and Crutzen (2004)).

\section{Conclusions and future research needs}

Our results show that even small levels of reactive bromine can greatly disturb tropospheric chemistry. Bromine related reactions strongly reduce ozone mixing ratios by up to $18 \%$ in zonal, annual mean values and up to $40 \%$ regionally. Furthermore, they also change the mixing ratios and speciation of the $\mathrm{HO}_{\mathrm{x}}$ and $\mathrm{NO}_{\mathrm{x}}$ chemical families. This highlights that both the photochemical production and destruction of $\mathrm{O}_{3}$ is perturbed by the presence of reactive bromine. A lower limit approach for $\mathrm{BrO}$ in the marine boundary layer, that does not explicitly treat the release of halogens from sea salt aerosol, showed that the mixing ratios of DMS in the MBL are strongly reduced due to the presence of $\mathrm{BrO}$ which in turn also leads to changes in the final products of the sulfur oxidation with potentially drastic changes for the cloud condensation nuclei population in the MBL.

While there is a substantial body of evidence for the presence of relevant levels of tropospheric $\mathrm{BrO}$ this needs to be supported with more direct and indirect measurements in all parts of the troposphere. In our model the widespread impact of bromine on tropospheric chemistry is caused by $\mathrm{BrO}$ mixing ratios that are around the detection limit of current instruments. For these reasons it is highly desirable to improve the detection limits, especially the sensitivity of space-borne instruments to $\mathrm{BrO}$ in the MBL to yield global coverage.
A first step to improve our knowledge about the global distribution of reactive bromine in the troposphere would be to conduct airborne studies in the free troposphere to check whether $\mathrm{BrO}$ is present at lower latitudes as well or if it is confined to high latitudes where it could already be directly measured.

An additional focus of future research in this field should be to investigate the contribution, spatial and temporal distribution of the different sources to global tropospheric bromine levels.

Acknowledgements. We thank C. Brühl for providing results from his 2D stratosphere model that we used to calculate the downward flux of bromine for the "strat" case. Many thanks to the reviewers, R. Sander, B.-M. Sinnhuber, and R. J. Salawitch for helpful comments on the ACPD version. This project was in part funded by the Deutsche Forschungsgemeinschaft DFG, Project GL353/1, MarHal.

Edited by: P. Monks

\section{References}

Abbatt, J. P. D.: Heterogeneous reaction of $\mathrm{HOBr}$ with $\mathrm{HBr}$ and $\mathrm{HCl}$ on ice surfaces at $228 \mathrm{~K}$, Geophys. Res. Lett., 21, 665-668, 1994.

Adams, J. W., Holmes, N. S., and Crowley, J. N.: Uptake and Reaction of $\mathrm{HOBr}$ on Frozen and dry Salt Surfaces, Atmos. Chem. Phys., 2, 79-91, 2002,

SRef-ID: 1680-7324/acp/2002-2-79.

Aranda, A., Le Bras, G., La Verdet, G., and Poulet, G.: The BrO $+\mathrm{CH}_{3} \mathrm{O}_{2}$ reaction: Kinetics and role in the atmospheric ozone budget, Geophys. Res. Lett., 24, 2745-2748, 1997.

Atkinson, A., Baulch, D. L., Cox, R. A., Hampson, Jr., R. F., Kerr, J. A., Rossi, M. J., and Troe, J.: Evaluated kinetic and photochemical data for atmospheric chemistry: Supplement VI, J. Phys. Chem. Ref. Data, 26, 1329-1499, 1997.

Atkinson, R., Baulch, D. L., Cox, R. A., Hampson, Jr., R. F., Kerr, J. A., Rossi, M. J., and Troe, J.: Summary of Evaluated Kinetic and Photochemical Data for Atmospheric Chemistry, Web Version, http://www.iupac-kinetic.ch.cam.ac.uk, 1999.

Atkinson, R., Baulch, D. L., Cox, R. A., Crowley, J. N., Hampson, R. F., Kerr, J. A., Rossi, M. J., and Troe, J.: Summary of Evaluated Kinetic and Photochemical Data for Atmospheric Chemistry, Web Version, Nov. 2003, http://www.iupac-kinetic.ch.cam. ac.uk, 2003.

Bobrowski, N., Hönninger, G., Galle, B., and Platt, U.: Detection of bromine monoxide in a volcanic plume, Nature, 423, 273-276, 2003.

Boucher, O., Moulin, C., Belviso, S., Aumont, O., Bopp, L., Cosme, E., von Kuhlmann, R., Lawrence, M. G., Pham, M., Redyy, M. S., Sciare, J., and Venkataraman, C.: Sensitivity study of dimethylsulphide (DMS) atmospheric concentrations and sulphate aerosol indirect radiative forcing to the DMS source representation and oxidation, Atmos. Chem. Phys., 3, 49-65, 2003, SRef-ID: 1680-7324/acp/2003-3-49. 
Brasseur, G. P., Orlando, J. J., and Tyndall, G. S. (Eds).: Atmospheric Chemistry and Global Change, Oxford University Press, New York, Oxford, 1999.

Brühl, C., Crutzen, P. J., and Grooß, J.: High-latitude, summertime $\mathrm{NO}_{\mathrm{x}}$ activation and seasonal ozone decline in the lower stratosphere: Model calculations based on observations by HALOE on UARS, J. Geophys. Res., 103, 3587-3597, 1998.

Crutzen, P. J. and Schmailzl, U.: Chemical budgets of the stratosphere, Planet. Space. Sci., 31, 1009-1032, 1983.

DeMore, W. B., Sander, S. P., Golden, D. M., Hampson, R. F., Kurylo, M. J., Howard, C. J., Ravishankara, A. R., Kolb, C. E., and Molina, M. J.: Chemical Kinetics and Photochemical Data for Use in Stratospheric Modeling, Tech. Rep. JPL Publication 97-4, Jet Propulsion Laboratory, Pasadena, CA, 1997.

Dentener, F. and Crutzen, P. J.: Reaction of $\mathrm{N}_{2} \mathrm{O}_{5}$ on Tropospheric Aerosols: Impact on the Global Distributions of $\mathrm{NO}_{\mathrm{x}}, \mathrm{O}_{3}, \mathrm{OH}$, J. Geophys. Res., 98, 7149-7163, 1993.

Fan, S.-M. and Jacob, D. J.: Surface ozone depletion in Arctic spring sustained by bromine reactions on aerosols, Nature, 359, 522-524, 1992.

Fickert, S., Adams, J. W., and Crowley, J. N.: Activation of $\mathrm{Br}_{2}$ and $\mathrm{BrCl}$ via uptake of $\mathrm{HOBr}$ onto aqueous salt solutions, J. Geophys. Res., 104, 23 719-23 727, 1999.

Fitzenberger, R., Bösch, H., Camy-Peyret, C., Chipperfield, M. P., Harder, H., Platt, U., Sinnhuber, B.-M., Wagner, T., and Pfeilsticker, K.: First Profile Measurements of Tropospheric BrO, Geophys. Res. Lett., 27, 2921-2924, 2000.

Harder, H., Camy-Peyret, C., Ferlemann, F., Fitzenberger, R., Hawat, T., Osterkamp, H., Schneider, M., Perner, D., Platt, U., Vradelis, P., and Pfeilsticker, K.: Stratospheric BrO profiles measured at different latitudes and seasons: Atmospheric observations, Geophys. Res. Lett., 25, 3843-3846, 1998.

Hausmann, M. and Platt, U.: Spectroscopic measurement of bromine oxide and ozone in the high Arctic during Polar Sunrise Experiment 1992, J. Geophys. Res., 99, 25 399-25 413, 1994.

Hebestreit, K., Stutz, J., Rosen, D., Matveiv, V., Peleg, M., Luria, M., and Platt, U.: DOAS Measurements of Tropospheric Bromine Oxide in Mid-Latitudes, Science, 283, 55-57, 1999.

Hollwedel, J., Wenig, M., Beirle, S., Kraus, S., Kühl, S., WilmsGrabe, W., Platt, U., and Wagner, T.: Year-to- Year Variability of Polar Tropospheric BrO as seen by GOME, Adv. Space Res., 34, 804-808, 2004.

Hönninger, G., Bobrowski, N., Palenque, E. R., Torrez, R., and Platt, U.: Reactive bromine and sulfur emissions at Salar de Uyuni, Bolivia, Geophys. Res. Lett., 31, doi: 10.1029/2003GL018 818, 2004.

Hubinger, S. and Nee, J. B.: Absorption spectra of $\mathrm{Cl}_{2}, \mathrm{Br}_{2}$ and $\mathrm{BrCl}$ between 190 and $600 \mathrm{~nm}$, J. Photochem. Photobiol. A: Chem., 86, 1-7, 1995.

Ingham, T., Bauer, D., Sander, R., Crutzen, P. J., and Crowley, J. N.: Kinetics and Products of the Reactions BrO + DMS and $\mathrm{Br}+\mathrm{DMS}$ at 298 K, J. Phys. Chem. A, 103, 7199-7209, 1999.

Jefferson, A., Nicovich, J. M., and Wine, P. H.: Temperaturedependent kinetics studies of the reactions $\operatorname{Br}\left({ }^{2} \mathrm{P}_{3 / 2}\right)+$ $\mathrm{CH}_{3} \mathrm{SCH}_{3} \leftrightarrow \mathrm{CH}_{3} \mathrm{SCH}_{2}+\mathrm{HBr}$. Heat of formation of the $\mathrm{CH}_{3} \mathrm{SCH}_{2}$ radical, J. Phys. Chem., 98, 7128-7135, 1994.

Jungwirth, P. and Tobias, D. J.: Ions at the Air/Water Interface, J. Phys. Chem. B, 106, 6361-6373, 2002.
Kettle, A. J., Andreae, M. O., Amouroux, D., Andreae, T. W., Bates, T. S., Berresheim., H., Bingemer, H., Boniforti, R., Curran, M. A. J., DiTullio, G. R., Helas, G., Jones, G. B., Keller, M. D., Kiene, R. P., Leck, C., Levasseur, M., Malin, G., Maspero, M., Matrai, P., McTaggart, A. R., Mihalopoulos, N., Nguyen, B. C., Novo, A., Putaud, J. P., Rapsomanikis, S., Roberts, G., Schebeske, G., Sharma, S., Simó, R., Staubes, R., Turner, S., and Uher, G.: A global database of sea surface dimethyl sulfide (DMS) measurements and a procedure to predict sea surface DMS as a function of latitude, longitude, and month, Global Biogeochem. Cycles, 13, 399-444, 1999.

Langner, J. and Rodhe, H.: A global three-dimensional model of the tropospheric sulfur cycle, J. Atmos. Chem., 13, 225-263, 1991.

Lawrence, M. G., Crutzen, P. J., Rasch, P. J., Eaton, B. E., and Mahowald, N. M.: A model for studies of tropospheric photochemistry: Description, global distributions, and evaluation, J. Geophys. Res., 104, 26 245-26277, 1999.

Lawrence, M. G., Jöckel, P., and von Kuhlmann, R.: What does the global mean $\mathrm{OH}$ concentration tell us?, Atmos. Chem. Phys., 1, 37-49, 2001,

\section{SRef-ID: 1680-7324/acp/2001-1-37.}

Leser, H., Hönninger, G., and Platt, U.: MAX-DOAS Measurements of $\mathrm{BrO}$ and $\mathrm{NO}_{2}$ in the Marine Boundary Layer, Geophys. Res. Lett., 30, 1537, doi:10.1029/2002GL015 811, 2003.

Mallard, W. G., Westley, F., Herron, J. T., Hampson, R. F., and Frizzel, D. H.: NIST Chemical Kinetics Database: Version 5.0, National Institute of Standards and Technology, Gaithersburg, MD, 1993.

McElroy, C. T., McLinden, C. A., and McConnell, J. C.: Evidence for bromine monoxide in the free troposphere during the Arctic polar sunrise, Nature, 397, 338-341, 1999.

Orlando, J. J. and Tyndall, G. S.: Rate coefficients for the thermal decomposition of $\mathrm{BrONO}_{2}$ and the heat of formation of BrONO 2 , J. Phys. Chem., 100, 19398-19405, 1996.

Platt, U. and Hönninger, G.: The role of halogen species in the troposphere, Chemosphere, 52, 325-338, 2003.

Pundt, I., Van Roozendael, M., Wagner, T., Richter, A., Chipperfield, M., Burrows, J. P., Fayt, C., Hendrick, F., Pfeilsticker, K., Platt, U., and Pommereau, J.-P.: Simultaneous UV-vis Measurements of BrO from Balloon, Satellite and Ground: Implications for Tropospheric BrO, in: Proc. Fifth European Symp. on Polar Stratospheric Ozone 1999. Air Poll. Res. Report 73, EUR 19340, European Commission, Brussels, Belgium, edited by: Harris, N. R. P., Guirlet, M., and Amanatidis, G. T., 316-319, 2000.

Richter, A., Wittrock, F., Ladstätter-Weißenmayer, A., and Burrows, J. P.: GOME measurements of stratospheric and tropospheric BrO, Adv. Space Res., 29, 1667-1672, 2002.

Saiz-Lopez, A., Plane, J. M. C., and Shillito, J. A.: Bromine oxide in the mid-latitude marine boundary layer, Geophys. Res. Lett., 31, doi:10.1029/2003GL018 956, 2004.

Sander, R., Rudich, Y., von Glasow, R., and Crutzen, P. J.: The role of $\mathrm{BrNO}_{3}$ in marine tropospheric chemistry: A model study, Geophys. Res. Lett., 26, 2857-2860, 1999.

Sander, S. P., Friedl, R. R., Golden, D. M., Kurylo, M. J., Huie, R. E., Orkin, V. L., Moortgat, G. K., Ravishankara, A. R., Kolb, C. E., Molina, M. J., and Finlayson-Pitts, B. J.: Chemical Kinetics and Photochemical Data for Use in Stratospheric Modeling, Tech. Rep. JPL Publication 02-25, Jet Propulsion Laboratory, Pasadena, CA, 2003. 
Singh, H. B. and Zimmerman, P. B.: Atmospheric distribution and sources of nonmethane hydrocarbons, Adv. Environ. Sci. Technol., 24, 177-235, 1992.

Stutz, J., Hebestreit, K., Alicke, B., and Platt, U.: Chemistry of Halogen Oxides in the Troposphere: Comparison of Model Calculations with Recent Field Data, J. Atmos. Chem., 34, 65-85, 1999.

Stutz, J., Ackermann, R., Fast, J. D., and Barrie, L.: Atmospheric Reactive Chlorine and Bromine at the Great Salt Lake, Utah, Geophys. Res. Lett., 29, doi:10.1029/2002GL014 812, 2002.

Toumi, R.: BrO as a sink for dimethylsulphide in the marine atmosphere, Geophys. Res. Lett., 21, 117-120, 1994.

Van Roozendael, M., Wagner, T., Richter, A., Pundt, I., Arlander, D. W., Burrows, J. P., Chipperfield, M., Fayt, C., Johnston, P. V., Lambert, J.-C., Kreher, K., Pfeilsticker, K., Platt, U., Pommereau, J.-P., Sinnhuber, B.-M., Tørnkvist, K. K., and Wittrock, F.: Intercomparision of BrO measurements from ERS-2 GOME, ground-based and balloon platforms, Adv. Space Res., 29, 16611666, 2002.

Vogt, R., Crutzen, P. J., and Sander, R.: A mechanism for halogen release from sea-salt aerosol in the remote marine boundary layer, Nature, 383, 327-330, 1996.

von Glasow, R. and Crutzen, P. J.: Tropospheric halogen chemistry, in: The Atmosphere, edited by: Keeling, R. F., Vol. 4, Treatise on Geochemistry, edited by: Holland, H. D. and Turekian, K. K., pp. 21-64, Elsevier-Pergamon, Oxford, 2003. von Glasow, R. and Crutzen, P. J.: Model study of multiphase DMS oxidation with a focus on halogens, Atmos. Chem. Phys., 4, 589608, 2004,

\section{SRef-ID: $1680-7324 / \mathbf{a c p} / \mathbf{2 0 0 4 - 4 - 5 8 9}$}

von Glasow, R., Sander, R., Bott, A., and Crutzen, P. J.: Modeling halogen chemistry in the marine boundary layer. 1 . Cloud-free MBL, J. Geophys. Res., 107, 4341, doi:10.1029/2001JD000 942, 2002a.

von Glasow, R., Sander, R., Bott, A., and Crutzen, P. J.: Modeling halogen chemistry in the marine boundary layer. 2. Interactions with sulfur and cloud-covered MBL, J. Geophys. Res., 107, 4323, doi:10.1029/2001JD000 943, 2002b.

von Kuhlmann, R., Lawrence, M. G., Crutzen, P. J., and Rasch, P. J.: A Model for Studies of Tropospheric Ozone and Non-Methane Hydrocarbons: Model Description and Ozone Results, J. Geophys. Res., 108, 4294, doi:10.1029/2002JD002 893, 2003.

Wagner, T. and Platt, U.: Satellite mapping of enhanced BrO concentrations in the troposphere, Nature, 395, 486-490, 1998.

Wagner, T., Leue, C., Wenig, M., Pfeilsticker, K., and Platt, U.: Spatial and temporal distribution of enhanced boundary layer $\mathrm{BrO}$ concentrations measured by the GOME instrumnet aboard ERS2, J. Geophys. Res., 106, 24 225-24 235, 2001.

WMO: Scientific assessment of ozone depletion: 2002, World Meteorological Organization, Global Ozone Research and Monitoring project, Report Nr. 47, 2003. 